\title{
Foraminiferal stratigraphy of Quaternary deposits in boring no. 51.12 Anholt, Kattegat
}

BY

ANNE-LISE LYKKE-ANDERSEN

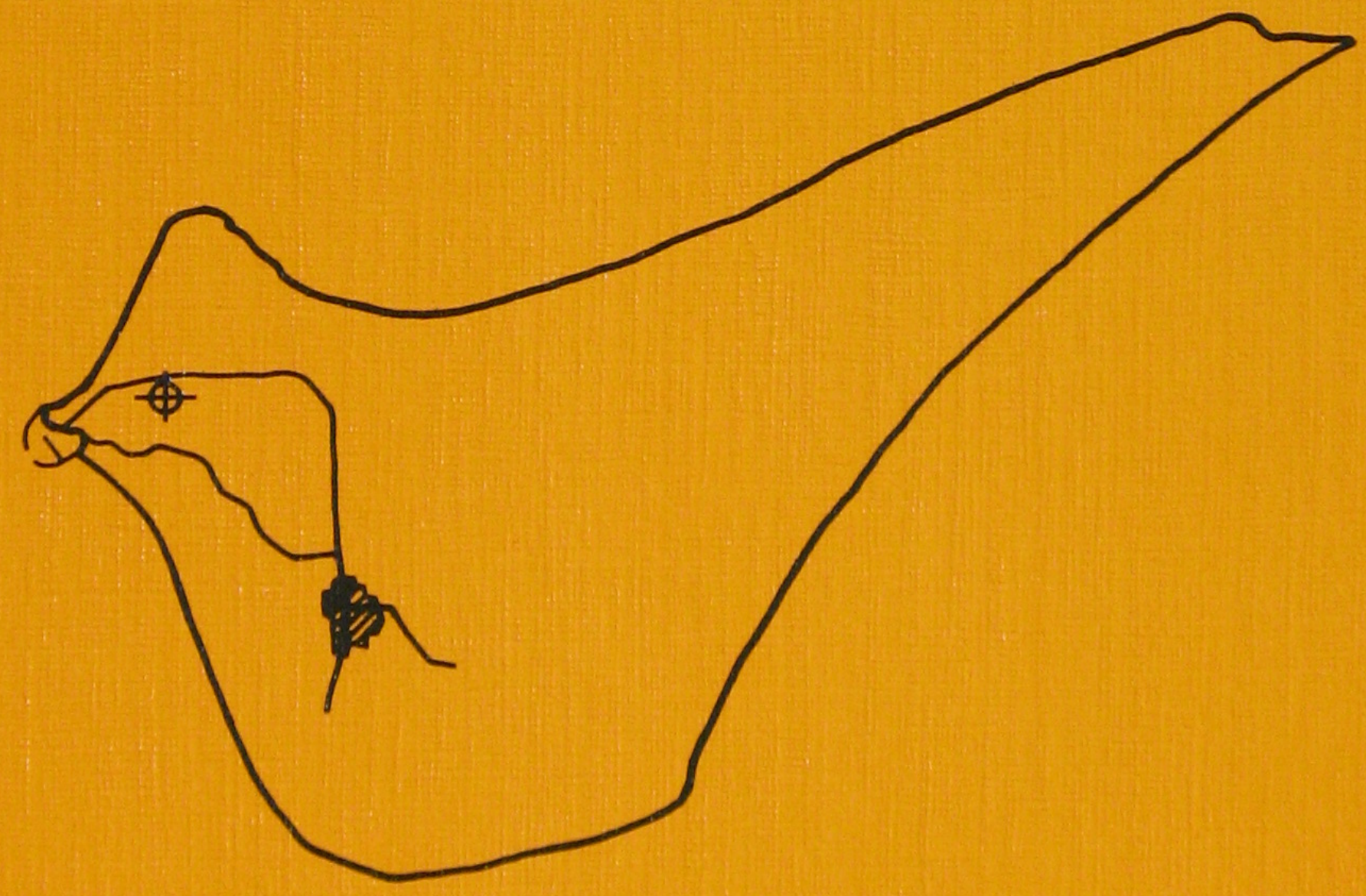




\section{Foraminiferal stratigraphy of Quaternary deposits in boring no. 51.12 Anholt, Kattegat}

BY

ANNE-LISE LYKKE-ANDERSEN 


\section{Key-words:}

Quaternary, Stratigraphy, Foraminifera, Saalian,

Eemian, Weichselian, Holocene.

Vignette:

The island of Anholt with the location

of boring no. 51.12 .

DGU $\cdot$ Serie B $\cdot$ Nr. 15

ISBN 87-88640-56-6

ISSN 0901-0289

Oplag: 1000

Tryk: AiO Tryk as, Odense

Tegning: Jette Gissel Nielsen

Foto: Ebbe Christensen (text-photos) and

Hans Jørgen Hansen (plates)

Dato: 1.9.199()

Anne-Lise Lykke-Andersen

Labyrinten 17, DK-8220 Brabrand, Denmark

Redaktion: Leif Banke Rasmussen

(C) Danmarks Geologiske Unders $ø$ gelse,

Thoravej 8, DK-2400 København NV.

I kommission hos: Geografforlaget Aps.

Ekspedition: Fruerhøjvej 43, 5464 Brenderup

Telefon 64441683 


\section{Preface}

This paper deals with a $229 \mathrm{~m}$ deep boring completed on Anholt in 1943. Substantial parts of the internal reports on the boring drawn up by the Geological Survey of Denmark but never published are sited in this paper. A. Nørvang examined and described the foraminiferal content of selected samples and on the basis of this made a suggestion on the paleoecology of part of the Quaternary penetrated by the boring. The method of sample-preparation used by Nørvang caused an underrepresentation of small-sized Foraminifera. Therefore it was concidered worthwhile to carry out a com- plementary new investigation of the foraminiferal content of the samples and cores which has been kept in the bore-archives at the Geological Survey of Denmark. The results of this new analysis are presented and on the basis of this, a stratigraphical interpretation of the Quaternary sequence is established. Although this interpretation should be taken with some reservation owing to the relatively poor quality of the samples, the analysis does provide some new aspects to the Quaternary geology in the Vendsyssel-Kattegat region. 


\section{Contents}

Abstract $\ldots \ldots \ldots \ldots \ldots \ldots \ldots \ldots . \quad 7 \quad$ Acknowledgements $\ldots \ldots \ldots \ldots \ldots . \ldots \ldots$

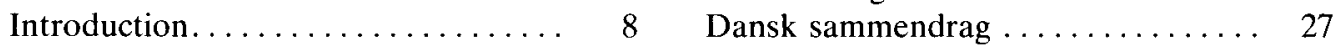

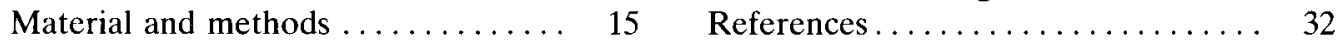

Zonation, correlation and age $\ldots \ldots .16 \quad$ Appendix $\ldots \ldots \ldots \ldots \ldots \ldots \ldots \ldots$

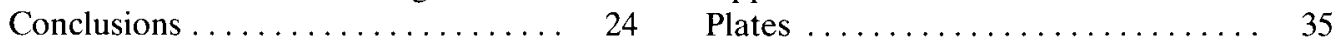

Foraminiferal list $\ldots \ldots \ldots \ldots \ldots \ldots .25 \quad$ Range chart $\ldots \ldots \ldots \ldots \ldots$ 


\section{Abstract}

Material from a $229 \mathrm{~m}$ deep boring on the island of Anholt in the central part of the Kattegat has been stratigraphically analysed on the basis of its foraminiferal content. Due to the lack of casing in the main part of the bore hole, only very few core samples and some samples from the drilling bit were not contaminated. The results of the foraminiferal analyses have, therefore, to be treated with some reservation.

The boring did not penetrate the Quaternary. The bottom $143 \mathrm{~m}$ of the boring represents deposits of pre-Eemian, possibly Saalian age. This interval seems to contain three marine interstadials, Anholt 1,2 and 3 , of which the upper interstadial is the warmest. Tills and glaciofluvial sediments are found between the marine sequences. The Eemian is represented by $13 \mathrm{~m}$ of marine deposits, which can be correlated with Ee- mian deposits known from other localities in the Vendsyssel-Kattegat region. They correspond to the Lower Turritella terebra Zone of the Skærumhede Series. The Early Weichselian and the lower part of the Middle Weichselian are missing, while the upper part of the Middle Weichselian, $32 \mathrm{~m}$ in all, is represented by marine deposits corresponding to foraminiferal zones known from the Vennebjerg Stadial and the Sandnes Interstadial in the Vendsyssel-Kattegat region. These Middle Weichselian zones correspond to the upper part of the Portlandia arctica Zone of the Skærumhede Series. The non-marine sequence on top of these deposits is considered to be glacial, belonging to the main Weichselian glacial event. Holocene littoral sands and gravels terminate the Quaternary sequence at Anholt. 


\section{Introduction}

In 1943 a $229 \mathrm{~m}$ deep boring was sunk on the island of Anholt in the Kattegat (figs. 1, 2, $3,4,5,6$ and 7) on the initiative of The Ministery of Public Works in Copenhagen. The management of the project was entrusted to the Geological Survey of Denmark.

The boring (Denm. Geol. Surv. file no. 51.12) and its geological results were described in internal reports (Gry et al. 1944; Hansen 1944). Helge Gry gave a general account of the geology of the boring (the discription of the sediments are shown in an appendix at p. 33). Axel Nørvang described the practical work in the field and he presented the results of the foraminiferal analyses. V. Nordmann examined the molluscs

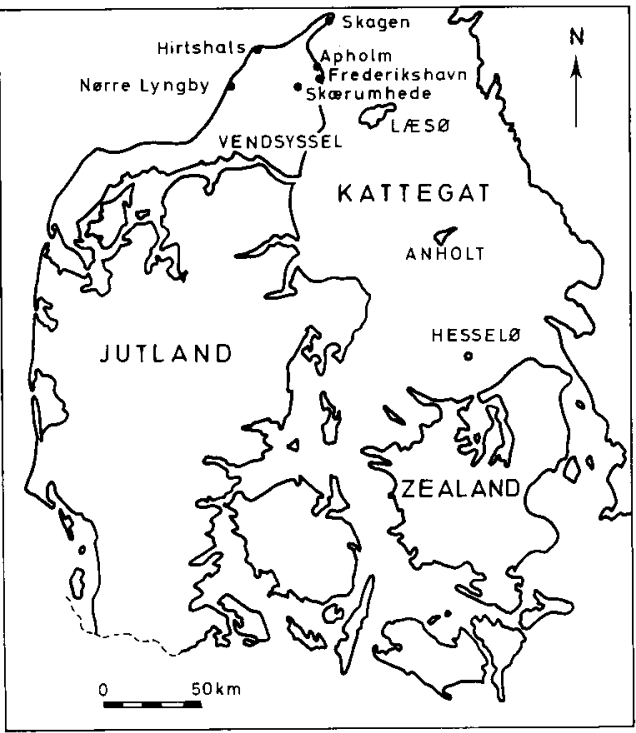

Fig. 1. Locality map.

Lokalitetskort. and Sigurd Hansen gave an account of the economy.

As the geological results of the Anholt boring have never been published it is summarized below.

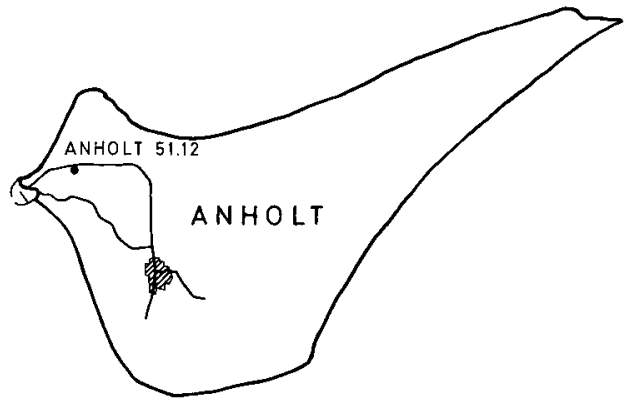

Fig. 2. The location of the Anholt boring no. 51.12. Anholt med placeringen af boring $n r .51 .12$.

The purpose of the boring on Anholt was to investigate the potential for coal in the Kattegat region. The background for this was the well-known fact that considerable amounts of coal occasionally can be found washed up on the beaches of e. g. Anholt. It was not known whether this originated from Tertiary (Miocene) or from Rhaetian-Liassic deposits. It was considered a possibility that the Kullen Horst which contains coal bearing deposits of Jurassic age (e. g. Bergström et al. 1982), extended in a northwest direction towards Anholt.

The boring was undertaken by "Produktionsaktieselskabet Undergrunden, Aarhus" using a standard rotary technique. The aim was to obtain undisturbed cores of the whole section. The odds for recovering these cores were, however, soon much reduced because the casing jammed at a depth of $34.48 \mathrm{~m}$. Only ten cores of variable 


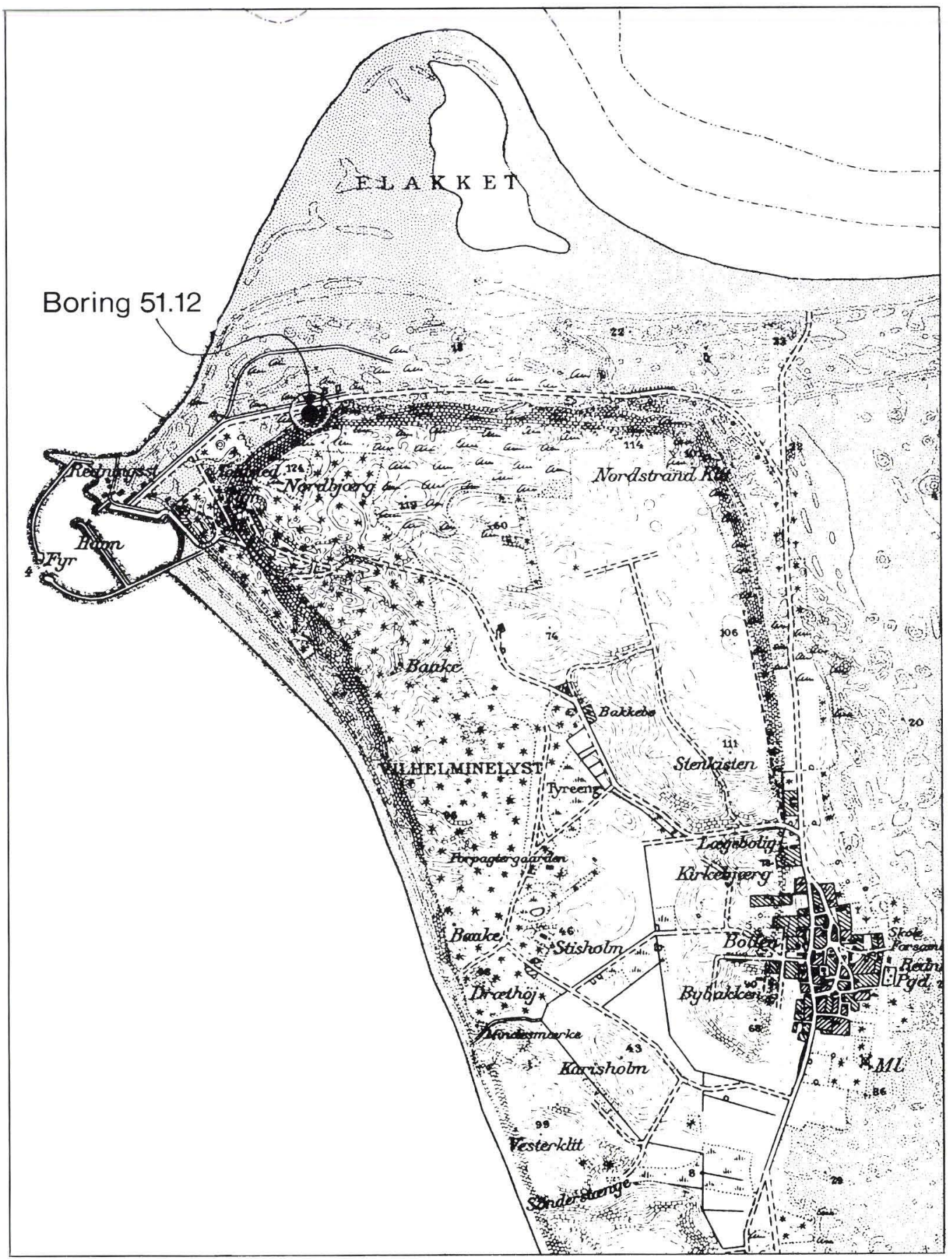

Fig. 3. Topographical map of the northwestern part of Anholt with the location of boring no. 51.12. From map sheet M 1623 (edit. 1935), scale: 1:20000.

Topografisk kort over den nordvestlige del af Anholt med borestedet. Del af geodaetisk Instituts blad M 1623 (udg. 1935) i 1:20000 (Reproduceret med tilladelse A 83 fra Kort-og Matrikelstyrelsen). 


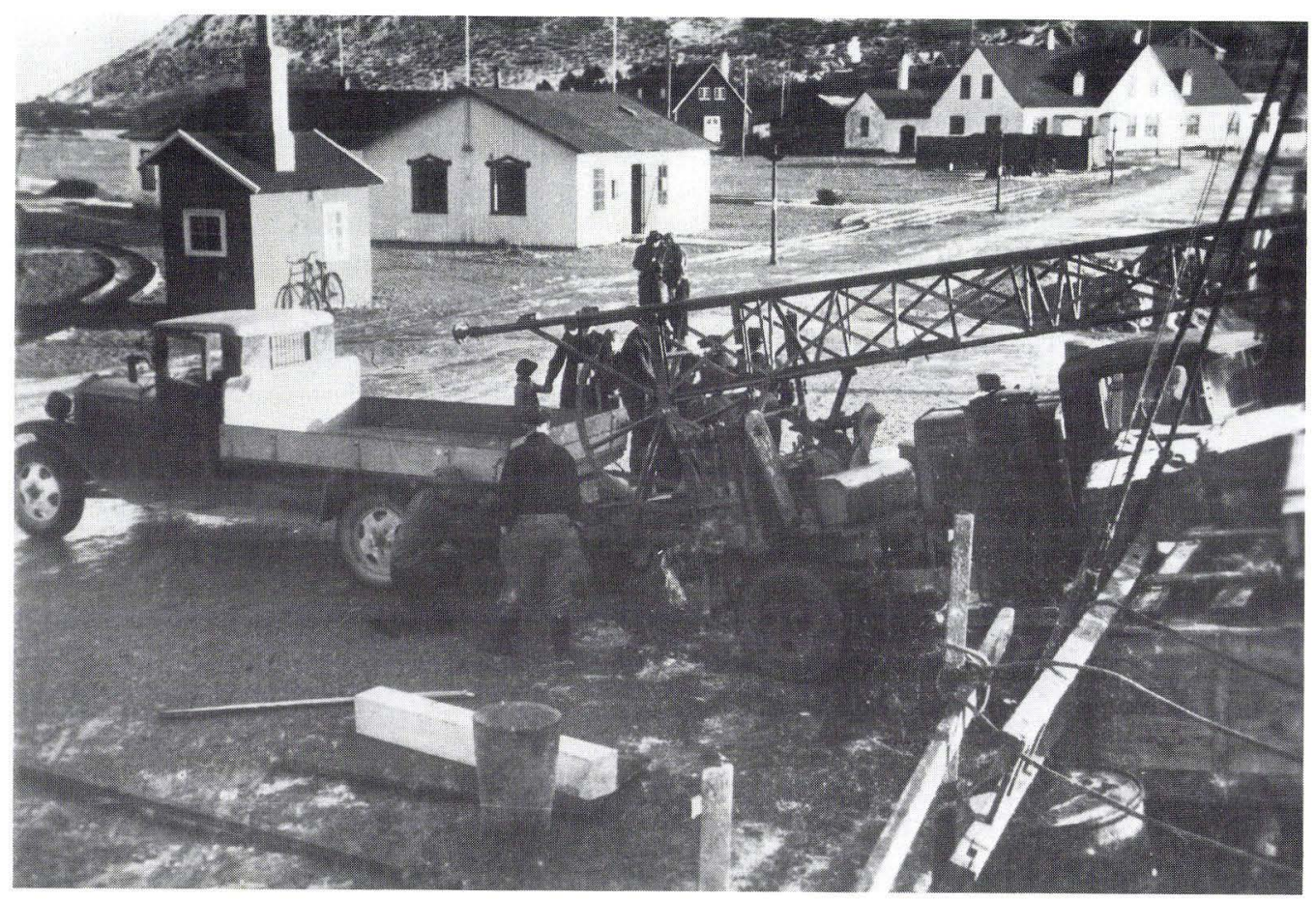

Fig. 4. Unloading of the bore rig in Anholt Harbour. Note the gas generator behind the drivers cabin on the lorry to the right.

Boretårnets ilandsatning $i$ Anholt Havn fra skibet. Bemark lastbilen med generatorgas-anlag.

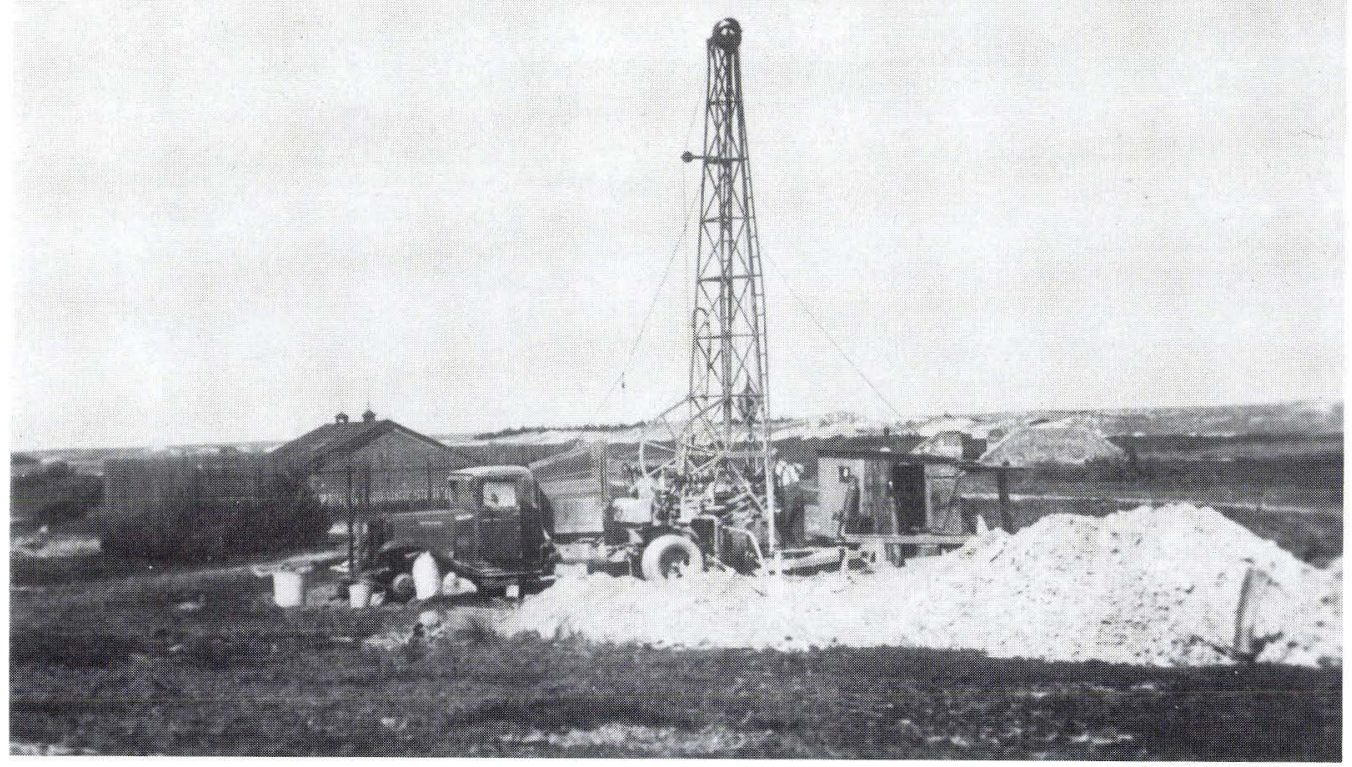

Fig. 5. The assembled rig in action. The northwestern part of Anholt. Flakket can be seen in the background.

Boreriggen opstillet og igang, med udsigt ud over Flakket. 
Fig. 6. A view of the bore rig, showing the equipment used. Nordbjerg's northern slope can be seen in the background.

Boretårnet set ind mod Nordbjergs nordskråning. Borerør og remedier ses $i$ forgrunden.

length, normally less than 2 to 3 metres, exist. Of these the upper core was useless owing to the fact that the core sampler here exclusively contained reworked material. Twenty-four samples were also taken from the drilling bit and a total of two hundred and nineteen samples were extracted from the drilling mud at an interval of about $1 \mathrm{~m}$, but due to the very short casing many of these samples may have been contaminated. The bore hole did not reach the base of the Pleistocene. After a series of accidents the drill stem broke at a depth of $228.81 \mathrm{~m}$.

Nordmann examined twenty-two samples from a depth of $62.7 \mathrm{~m}$ to bottom. He con-

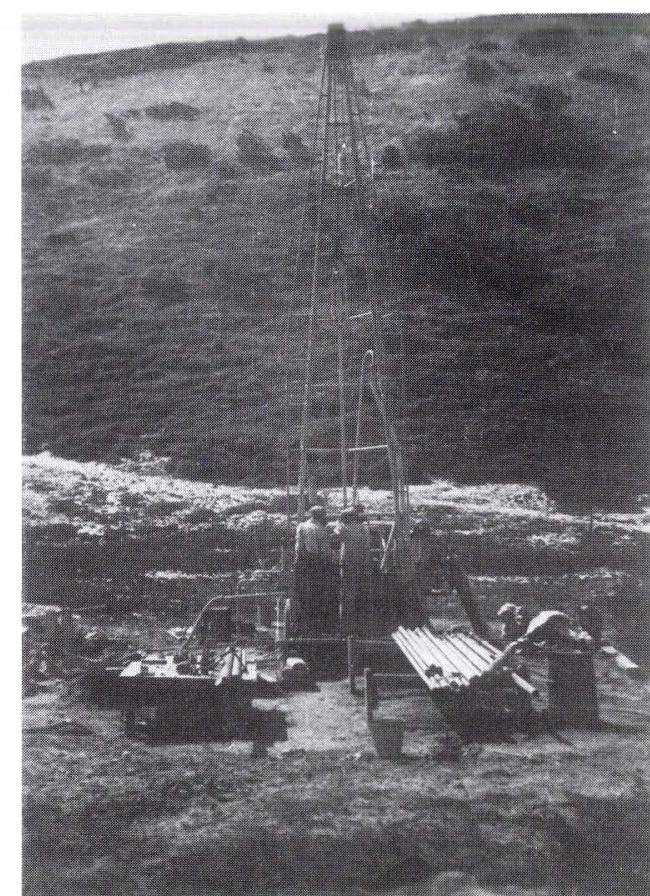

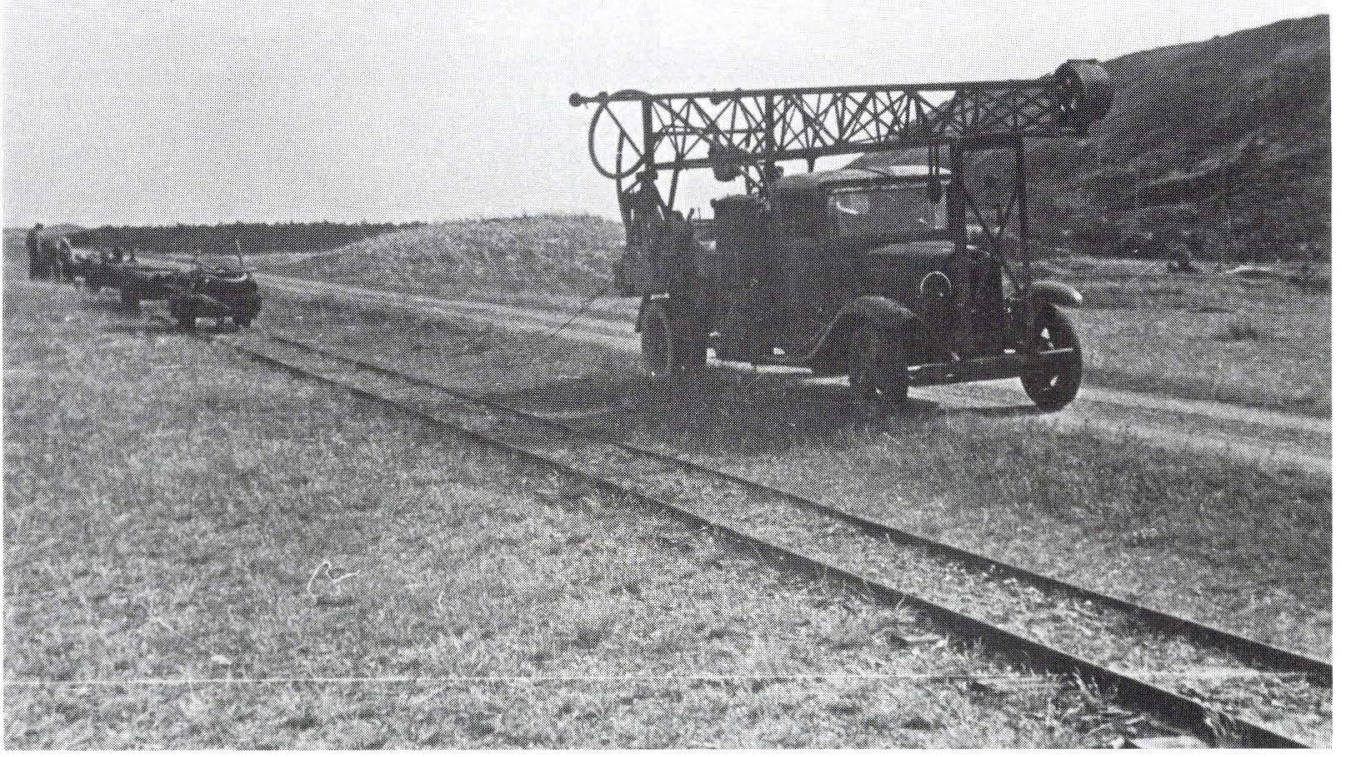

Fig. 7. Transportation of the bore rig from the drilling site to the harbour on the gas-driven lorry. The narrow-gauge railway dates from the time the harbour was built. This was also used to transport bore equipment and the collected material. The slope in the background is Nordbjerg.

Borttransportering af boreriggen på den gamle lastbil med generatorgas-anlag. Sporanlagget, som stammer fra havnebyggeriets tid, blev også anvendt til transport af remedierne. Nordbjergs skraenter haver sig $i$ baggrunden. 
cluded that the sediments between 62.7 and $70.7 \mathrm{~m}$ were marine in origin and suggested that the intervals from $73.7-76 \mathrm{~m}$ and $103-$ $105 \mathrm{~m}$ depth may also be marine (fig. 8). Nordmann characterized the molluscs in these intervals as boreal with a southern affinity. He pointed out that the assemblages were not correlatable with any of the known interglacial faunas, neither the lusitanien Eemian fauna known from the southern part of Denmark nor the faunas of the Skærumhede Series, though they did, nevertheless, resemble the faunas of the Turritella terebra Zone of the Skærumhede Series (Jessen et al. 1910).

Nørvang analysed the foraminiferal faunas of twenty-eight samples including seventeen from the drilling bit. He subdivided part of the sequence into five foraminiferal fauna zones, viz. series I-V (fig. 8).

\section{ANHOLT 51.12}

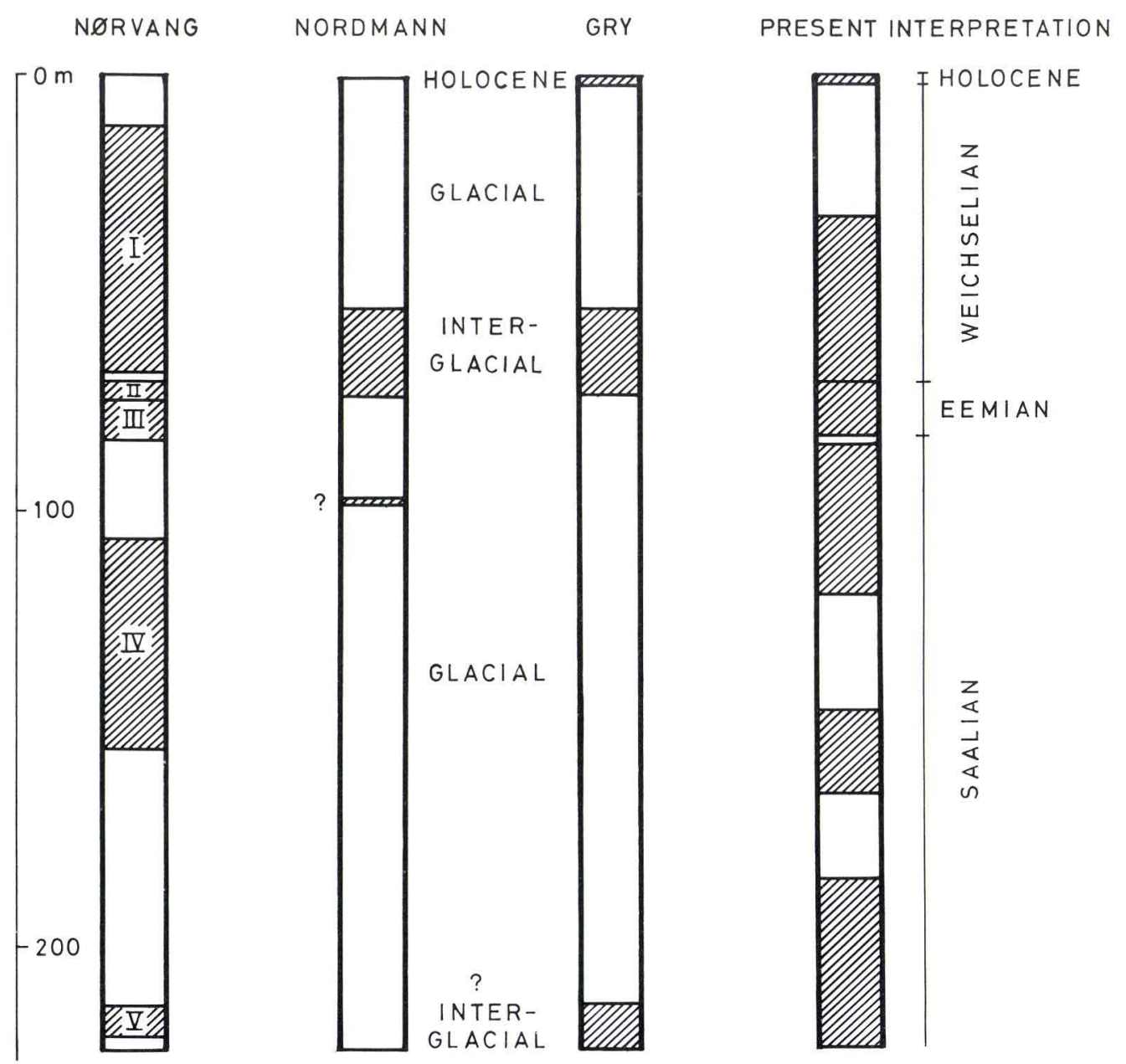

Fig. 8. An outline of the results of the investigations of Anholt boring no. 51.12. Hatching represents marine intervals. Nфrvangs series I-V is explained in the text.

Oversigt over resultaterne af undersфgelserne af boring $n r .51 .12$, Anholt. De skraverede områder reprasenterer marine intervaller. Nørvangs serie I-V er forklaret $i$ teksten. 
The series I $(13.9-70.7 \mathrm{~m})$ faunas were characterized by species from arctic environments. The faunas were, however, rather sparse and he found it, therefore, difficult to decide whether these deposits were marine or fluvial.

Series II (73.7-79.7 m) consisted of a marine sequence with southern boreal foraminiferal faunas. This series showed a gradual upwards fall in temperature. High density, species-rich assemblages were present in all samples.

Series III (79.7-85.7 $\mathrm{m})$ only included two samples from the drilling mud. Nørvang found faunas which consisted of both boreal and arctic species in these samples. He discussed the origin of this series and concluded that it might be either a local till composed of different marine clays or a marine arctic stony clay with arctic foraminiferal faunas, but contaminated by the overlying boreal faunas. He stressed in any case the presence of arctic Foraminifera under series II deposits.

The samples examined by Nørvang from series IV (109.7-157.7 m) were characterized by their sparsity of Foraminifera. It was not possible to determinate whether the sediments were of marine or fluvial origin.

The foraminiferal faunas of series $\mathrm{V}$ $(215.8-224.7 \mathrm{~m})$ were mainly arctic in character with an element of boreal species. Nørvang called these mixed faunas. He did not comment on the possible origin of this series.

In the geological part of the internal report Gry concluded that the Quaternary deposits of the Anholt boring could be subdivided as follows (see also fig. 8):

\section{0- $3,0 \mathrm{~m}$ marine Holocene sand and gravel \\ $3,0-56.5 \mathrm{~m}$ mainly glaciofluvial deposits and tills (maybe with mari- ne arctic clays from 43.7 to $45.2 \mathrm{~m}$ )}

56.5- $77.2 \mathrm{~m}$ marine boreal interglacial (compared with the Turri- tella terebra Zone of the Skærumhede Series)

77.2-228.81 m mainly glaciofluvial deposits and till possibly with interglacial (marine) layers near the bottom

Though the boring did not penetrate the Quaternary deposits it gave valuable information about the pre-Quaternary, namely that Anholt is not situated in a horst region and that the possibility of finding RhaetianLiassic coal bearing sediments is thereby excluded.

Gry explained the deep position of the pre-Quaternary surface as either a result of glacial erosion or of tectonic movement along faults. He considered it most likely that the northwest-southeast trending valley known from Skåne as the Alnarp-Valley, which extends across Northeast Sjælland, continues as far as Anholt and that this basin had played a role in the transgression of the Skærumhede Sea.

Mörner (1969) interpreted the stratigraphy of the boring at Anholt in the following way:

A: $\quad$ To $72.7 \mathrm{~m}$ an upper drift series $=$ the Upper Pleniglacial (of the Netherlands).

B: To $77.2 \mathrm{~m}$ marine clay $=$ part of the Portlandia arctica Zone (57.4-74.4 m) of the Skærumhede I boring and the Interpleniglacial of the Netherlands.

C: To $228.8 \mathrm{~m}$ a lower drift series $=$ the ice marginal deposits of the Lower Pleniglacial (of the Netherlands).

The "lower drift series" was considered to comprise deposits accumulated in front of the Weichselian "Old Baltic Ice" (about 50, 000 B.P.), which according to Mörner occupied at its maximum the eastern and southern part of Kattegat, extending to a line from Djursland to a point east of Anholt and further north to a point east of the island of Læsø. 
"The Anholt Stadial" was proposed as a local name for this ice advance.

The purpose of the present investigation is to establish as detailed a foraminiferal zonation of the Quaternary deposits in the Anholt boring as possible and to place this within the regional chronology for the Kattegat region (Lykke-Andersen 1987). The knowledge obtained could furthermore further our knowledge about basin development in this part of Kattegat. 


\section{Material and methods}

Most of the samples from the Anholt boring are as mentioned above of rather poor quality. This is primarily'due to the lack of casing in the main part of the bore hole, which increases the risk for contamination, particularly in the ditch samples. Secondly, the use of Holocene marine clays as drilling mud in the lowermost part of the bore hole $(210-228.81 \mathrm{~m})$ has reduced the value of the samples in this interval. Fortunately, a sample of the drilling mud had been stored, and the degree of contamination caused by its use as a drilling mud could be estimated.

The majority of samples used in this investigation are, therefore, cores and samples from the drilling bit. The ditch samples were also examined, but they have only been used in the intervals where other samples were missing or where they support the other types of samples.

The samples were processed using standard techniques (Feyling-Hanssen et al. 1971; Meldgaard \& Knudsen 1979) with one minor alteration. Each sample were washed through sieves with mesh diameters of $63 \mu$ and $1 \mathrm{~mm}$. The use of $63 \mu$ instead of 0.1 $\mathrm{mm}$, as is normally used, was due to the fact that very many small species of Foraminifera was found in some of the samples. The frequency distribution of selected species is illustrated in fig. 9 together with other parameters, including the faunal diversity (Walton 1964) and boreal content (Knudsen 1984). 


\section{Zonation, correlation and age}

The Anholt boring penetrated a Quaternary sequence which has been subdivided into eleven zones, (A-K: fig. 9). This zonation is very broad due to the poor condition of the samples.

\section{Holocene}

\section{Zone A}

The uppermost part of the sequence consists of shelly sands and gravels $(0-3 \mathrm{~m})$, belonging to the Holocene (Gry et al. 1944). Though these sediments are marine, they only contain a few Foraminifera, possibly due to dissolution. The Foraminifera which have been preserved are often filled with pyrite. These are not included in the diagram (fig. 9). This part of the boring is here called zone A.

\section{Weichselian}

\section{Zone B}

The sediments of zone B (3-34 m) are composed of different layers of sand, clay and sandy clay occasionally with stones (fig. 9).

Most of the samples from zone B contain Foraminifera. The high pre-Quaternary foraminiferal content indicates, however, that the faunas are presumably redeposited. In addition it is noteworthy that the faunas are the same as these present in the underlying marine zone (zone $\mathrm{C}$ ).
The units composed of stony and sandy clays are therefore considered to be tills (20.1-21.7 m, 22.3-23.3 $\mathrm{m}$ and 25-26.55 m) and the intervening layers as glaciofluvial sediments, all belonging to the Late Weichselian. For the Middle Weichselian-Late Weichselian boundary an age of 25,000 B.P. (Mangerud \& Berglund 1978) has been used.

No marine Late Weichselian sediments were identified. This does not mean that marine deposits are lacking, but may be due to the aforementioned problems encountered during boring.

\section{Zone C}

Compact clays with stones and shells were found in zone C (34-43 m). Elphidium excavatum and Cassidulina reniforme account for $34-47 \%$ and $15-28 \%$ of the foraminiferal faunas, respectively. Other important species include Bulimina marginata, Elphidium albiumbilicatum and Buccella frigida together with Nonion labradoricum, $N$. orbiculare and Islandiella norcrossi. The faunal diversity and the boreal content are both rather high, as is the pre-Quaternary foraminiferal content (fig. 9).

As an example of the foraminiferal assemblage of zone $C$, the analysis of sample no. 51 is presented below. The count represents about $15 \%$ of the sample $(100 \mathrm{~g})$ : 


\begin{tabular}{|c|c|c|}
\hline \multirow{2}{*}{$\begin{array}{l}\text { Species } \\
\text { Elphidium excavatum }\end{array}$} & \multicolumn{2}{|c|}{ Frequency Percentage } \\
\hline & 124 & 34 \\
\hline Cassidulina reniforme & 95 & 26 \\
\hline Bulimina marginata & 37 & 10 \\
\hline Elphidium albiumbilicatum & 24 & 7 \\
\hline Buccella frigida & 15 & 4 \\
\hline Epistominella vitrea & 7 & 2 \\
\hline Pullenia osloensis & 6 & 2 \\
\hline Angulogerina fluens & 5 & 1 \\
\hline Epistominella takayanagii & 5 & 1 \\
\hline Nonion labradoricum & 5 & 1 \\
\hline Cassidulina laevigata & 4 & 1 \\
\hline Nonion orbiculare & 4 & 1 \\
\hline Nonionella iridea & 4 & 1 \\
\hline Buliminella elegantissima & 3 & 1 \\
\hline Bolivina cf. robusta & 3 & 1 \\
\hline Nonion depressulum & 3 & 1 \\
\hline Lagena sulcata laevicostata & 2 & 1 \\
\hline Islandiella helenae & 2 & 1 \\
\hline Islandiella norcrossi & 2 & 1 \\
\hline Hyalinea balthica & 2 & 1 \\
\hline Astrononion gallowayi & 2 & 1 \\
\hline Pyrgo williamsoni & 1 & $<0.5$ \\
\hline Miliolinella subrotunda & 1 & $<0.5$ \\
\hline Fissurina danica & 1 & $<0.5$ \\
\hline Fissurina laevigata & 1 & $<0.5$ \\
\hline $\begin{array}{l}\text { Parafissurina himatiostoma } \\
\text { Parafissurina lateralis }\end{array}$ & 1 & $<0.5$ \\
\hline f.carinata & 1 & $<0.5$ \\
\hline Globobulimina auriculata & & \\
\hline arctica & 1 & $<0.5$ \\
\hline Stainforthia fusiformis & 1 & $<0.5$ \\
\hline Uvigerina peregrina & 1 & $<0.5$ \\
\hline Cibicides lobatulus & 1 & $<0.5$ \\
\hline Elphidium groenlandicum & 1 & $<0.5$ \\
\hline Total & 365 & \\
\hline
\end{tabular}

The zone $\mathrm{C}$ faunas are arctic with a boreal element indicating moderate water depths with a minimum depth of about $20 \mathrm{~m}$. This fauna is referred to foraminiferal assemblage zone I, the Nonion labradoricum-Islandiella norcrossi Zone of the VendsysselKattegat region (Lykke-Andersen 1971, 1987; Konradi \& Knudsen 1974; Knudsen 1986), which has been correlated with the Middle Weichselian Sandnes Interstadial in Southwest Norway (Feyling-Hanssen 1971).

\section{Zone D}

Zone D (43-72.7 m) is composed of the same stony and shelly, compact clays as zone $\mathrm{C}$ down to $67 \mathrm{~m}$ depth and thereafter of sand with shell-fragments. The faunas of this zone contain very few boreal specimens (fig. 9). Elphidium excavatum (43-66\%) and Cassidulina reniforme (25-39\%) dominate the faunas even more than in zone C. The faunal diversity is consequently lower, as is the number of species. The most important accessory species are Elphidium asklundi, Nonion orbiculare, Buccella frigida, Islandiella norcrossi and Nonion labradoricum.

Sample no. $67 \mathrm{c}(100 \mathrm{~g})$ of which about $18 \%$ was counted, contains an assemblage as shown below:

\begin{tabular}{lrc}
\hline Species & Frequency & Percentage \\
\hline Elphidium excavatum & 303 & 60 \\
Cassidulina reniforme & 170 & 34 \\
Islandiella norcrossi & 8 & 2 \\
Elphidium asklundi & 6 & 1 \\
Nonion labradoricum & 5 & 1 \\
Stainforthia loeblichi & 4 & 1 \\
Nonion orbiculare & 4 & 1 \\
Pyrgo williamsoni & 1 & $<0.5$ \\
Guttulina lactea & 1 & $<0.5$ \\
Parafissurina sp. & 1 & $<0.5$ \\
Buccella frigida & 1 & $<0.5$ \\
Buccella tenerrima & 1 & $<0.5$ \\
Astrononion gallowayi & 1 & $<0.5$ \\
Elphidium albiumbilicatum & 1 & $<0.5$ \\
\hline Total & 507 & \\
\hline
\end{tabular}

The assemblages of zone $\mathrm{D}$ are arctic from rather shallow water environments. These faunas are identical with those found in foraminiferal assemblage zone II, the Elphidium asklundi-Nonion orbiculare Zone of the Vendsyssel-Kattegat region (Lykke-Andersen 1971, 1987; Konradi \& Knudsen 1974; Knudsen 1986). This zone has been placed in the Middle Weichselian Vennebjerg Stadial (Lykke-Andersen \& Knudsen 1990). 
Radiocarbon dates from the corresponding zone at Hirtshals have yielded ages of at least 34,000 B.P. (Lykke-Andersen 1982). New radiocarbon dates using the accelerator mass spectrometry facility at Aarhus University (molluses and Foraminifera) gave ages of $31,500 \pm 2100$ and $32,700 \pm 2400 \mathrm{~B}$. P. (Thomsen 1990).

The present study shows that the deposits between 3 and $72.7 \mathrm{~m}$ depth belong to the Late and Middle Weichselian (fig 9). The Middle Weichselian marine sequence can also be correlated with part of the Portlandia arctica Zone of the Skærumhede I boring (Jessen et al. 1910).

Series I of Nørvang (Gry et al. 1944) includes the greatest part of zones B, C and D. Nørvang found it difficult to decide whether this sequence was marine or fluvial (see above).

Nordmann examined three samples from zone $\mathrm{D}$ and found that they were all marine due to their content of very well preserved mollusc fragments. Actually this was the only sequence Nordmann with certainty identified as marine (see above).

Gry concluded that only the lowermost part of zone $\mathrm{D}$ was definitely of marine origin, though he did not reject the possibility that the upper part of zone D was also marine. He, unfortunately, combined this part of the boring with the subjacent interglacial sequence (zone $\mathrm{E}$ of this investigation).

\section{Eemian}

\section{Zone $\mathbf{E}$}

An abrupt change in both sediment type and faunal composition occur at $72.7 \mathrm{~m}$ (fig. 9). Zone $\mathrm{E}(72.7-83.7 \mathrm{~m})$ consists of about five metres of sticky, shell-rich clays underlain by alternating layers of shelly sand and clay. Boreal and boreal-lusitanian deeper water Foraminifera are important faunal elements in this zone. Bulimina marginata dominates, accounting for 30 to $73 \%$ of the faunas. Other frequent species are Hyalinea balthica, Cassidulina laevigata, Pullenia osloensis and Elphidium excavatum. Epistominella vitrea is also important. Boreal-lusitanian species such as Planulina ariminensis, Textularia sagittula, Bolivina subspinescens, Globobulimina turgida, Nonion barleeanum, Angulogerina angulosa and the lusitanian Quinqueloculina padana are characteristic elements of the fauna. The number of specimens is very high, as is the number of species, the faunal diversity and the boreal content.

The assemblage of sample no. $112 \mathrm{~d}$ is shown below. The foraminiferal content of about $2 \%$ of the sample $(100 \mathrm{~g})$ was counted:

\begin{tabular}{|c|c|c|}
\hline Species & Frequency & Percentage \\
\hline Bulimina marginata & 724 & 65 \\
\hline Hyalinea balthica & 110 & 10 \\
\hline Elphidium excavatum & 79 & 7 \\
\hline Epistominella vitrea & 38 & 3 \\
\hline Cassidulina laevigata & 34 & 3 \\
\hline Stainforthia fusiformis & 28 & 3 \\
\hline Pullenia osloensis & 23 & 2 \\
\hline Nonionella iridea & 11 & 1 \\
\hline Fissurina danica & 9 & 1 \\
\hline Textularia sagittula & 5 & $<0.5$ \\
\hline Amphicoryna scalaris & 5 & $<0.5$ \\
\hline Bolivina subspinescens & 5 & $<0.5$ \\
\hline \multicolumn{3}{|l|}{ Quinqueloculina } \\
\hline seminulum & 4 & $<0.5$ \\
\hline Cassidulina reniforme & 3 & $<0.5$ \\
\hline Nonionella turgida & 3 & $<0.5$ \\
\hline Lagena striata & 2 & $<0.5$ \\
\hline Uvigerina peregrina & 2 & $<0.5$ \\
\hline Cibicides lobatulus & 2 & $<0.5$ \\
\hline Nonion barleeanum & 2 & $<0.5$ \\
\hline Ammonia batava & 2 & $<0.5$ \\
\hline Spiroloculina rotunda & 1 & $<0.5$ \\
\hline Pyrgo williamsoni & 1 & $<0.5$ \\
\hline Sigmoilopsis schlumbergeri & 1 & $<0.5$ \\
\hline Dentalina sp. & 1 & $<0.5$ \\
\hline Lenticulina sp. & 1 & $<0.5$ \\
\hline Lagena distoma & 1 & $<0.5$ \\
\hline Lagena sulcata laevicostata & 1 & $<0.5$ \\
\hline Fissurina lucida & 1 & $<0.5$ \\
\hline Parafissurina later. f. carin. & 1 & $<0.5$ \\
\hline Stainforthia loeblichi & 1 & $<0.5$ \\
\hline Angulogerina angulosa & 1 & $<0.5$ \\
\hline Bolivina cf. robusta & 1 & $<0.5$ \\
\hline Buccella frigida & 1 & $<0.5$ \\
\hline Anomalina globulosa & 1 & $<0.5$ \\
\hline
\end{tabular}


Species

Frequency Percentage

Planulina ariminensis

Nonion depressulum

Elphidium macellum

Elphidium williamsoni

Total

1109
$<0.5$

$<0.5$

$<0.5$

$<0.5$

This fauna indicates climatic conditions at least as warm as today and water depths of about 50 to $100 \mathrm{~m}$. The very high number of specimens indicates low sedimentation rates during the warmest period in the Eemian. The faunas in the uppermost part of the zone suggest shallower conditions and perhaps also a drop in temperature. The lowermost part of the section, from which only ditch samples were available, include species from colder and shallower waters.

The majority of the faunas in zone $\mathrm{E}$ are identical to faunas known from the Lower Turritella terebra Zone of the Skærumhede Series. In the Vendsyssel-Kattegat region this foraminiferal assemblage zone is called zone X, the Bulimina marginata-Quinqueloculina padana Zone (Lykke-Andersen 1987), and has been placed in the Eemian Interglacial (Feyling-Hanssen et al. 1971; Knudsen \& Lykke-Andersen 1982; Knudsen 1984, 1985; Lykke-Andersen 1987; Lykke-Andersen \& Knudsen 1990).

Amino acid measurements on Bulimina marginata from sample no. $112 \mathrm{~d}$ gave an alle/lle ratio of 0.083 (BAL 443). This corresponds to values known from the Eemian in the North Sea region (Knudsen \& Sejrup 1988), and thus complements the conclusions based on the foraminiferal faunas.

Nørvang (Gry et al. 1944) called this section of the Anholt boring series II and III (see above). He considered both series to be marine. He interpreted the faunas of series II as southern boreal. Species preferring colder climates were only present at the top of this series. He characterized the foraminiferal faunas of series III as a mixed fauna,

and he pointed out the presence of an aretic faunal element in layers older than the boreal faunas of series II.

Nordmann examined two samples from this section and concluded that one of them could be marine (see above).

Gry concluded that this part of the boring represented a marine boreal interglacial. These interglacial deposits $(56.5-77.2 \mathrm{~m})$ were correlated with the Turritella terebra Zone of the Skærumhede Series (Jessen et al. 1910) but they were not referred to any known interglacial period (fig. 8).

Mörner (1969) referred this interval to part of the Portlandia arctica Zone (57.4 $74.4 \mathrm{~m}$ ) of the Skærumhede Series (Jessen et al. 1910), which belongs to the Middle Weichselian Sandnes Interstadial and Vennebjerg Stadial (Lykke-Andersen \& Knudsen 1990).

\section{Pre-Eemian}

\section{Zone F}

The interval between 85.7 and $87.9 \mathrm{~m}$, zone $\mathrm{F}$, comprises stony sands with considerable amounts of bryozoans. The character of the sediment, together with the fact that core samples from this unit contain thousands of pre-Quaternary Foraminifera and only a few Quaternary specimens per $100 \mathrm{~g}$, suggests that it might be a till or a glaciofluvial deposit (fig. 9). This very characteristic zone must belong to a glacial period older than the Eemian, in all probability the Saalian (sensu lato).

It is noteworthy that the Skærumhede I boring also includes a section rich in bryozoans below the Eemian sequence, namely the uppermost part of the "lower glacial beds" (Jessen et al. 1910; Knudsen \& Lykke-Andersen 1982).

Nørvang did not study samples from this zone and Nordmann only looked at one sample, which he did not comment on (Gry et al. 1944). 


\section{Zone G}

Zone $\mathrm{G}(87.9-125 \mathrm{~m})$ is composed of thin alternating layers of sand and clay with some shell-fragments. A $2.5 \mathrm{~m}$ thick sand unit occurs between 98 and $100.5 \mathrm{~m}$ depth (fig. 9). No core samples were obtained from these sediments. Only five samples from the drilling bit were available in addition to the ditch samples.

All samples from zone $G$ contain between 500 and 1000 Quaternary Foraminifera per $100 \mathrm{~g}$ sediment. Elphidium excavatum and Bulimina marginata dominate. Other important species are Cassidulina reniforme, C. laevigata and Hyalinea balthica. Buccella frigida, Nonion orbiculare, $N$. labradoricum, Islandiella helenae and I. norcrossi are characteristic accessory species. The frequency of boreal forms, including Bulimina marginata, is very high in the ditch samples,

\begin{tabular}{lcc}
\hline Species & Frequency & Percentage \\
\hline Bulimina marginata & 66 & 44 \\
Elphidium excavatum & 33 & 22 \\
Cassidulina laevigata & 9 & 6 \\
Cassidulina reniforme & 9 & 6 \\
Hyalinea balthica & 9 & 6 \\
Epistominella vitrea & 5 & 5 \\
Textularia sagittula & 2 & 1 \\
Angulogerina angulosa & 2 & 1 \\
Buccella frigida & 2 & 1 \\
Nonion labradoricum & 2 & 1 \\
Pyrgo williamsoni & 1 & 1 \\
Stainforthia loeblichi & 1 & 1 \\
Angulogerina fluens & 1 & 1 \\
Islandiella helenae & 1 & 1 \\
Islandiella norcrossi & 1 & 1 \\
Nonion barleeanum & 1 & 1 \\
Nonion orbiculare & 1 & 1 \\
Nonionella iridea & 1 & 1 \\
Pullenia osloensis & 1 & 1 \\
Elphidium albiumbilicatum & 1 & 1 \\
Elphidium bartletti & 1 & 1 \\
Ammonia batava & 1 & 1 \\
\hline Total & 151 & \\
\hline
\end{tabular}

while the arctic forms play a greater role in the samples from the drilling bit. This is in all probability a function of contamination from above, especially in the case of the ditch samples. Consequently only the samples taken from the drilling bit have been used in interpretating the faunas.

The foramiferal analysis of sample no. $171(13 \mathrm{~g})$ is shown as an example of the zone $\mathrm{G}$ faunas.

The apparent foraminiferal content of these samples indicates that the sediments are marine. The faunas belong to boreal to borealarctic palaeoenvironments with moderate water depths.

Zone $\mathrm{G}$ may correspond to an interstadial period. It is here called Anholt 1 and is referred to the Saalian Glaciation. There is, however, no evidence of an age other than its location in the sequence in the boring. If zone $G$ was not separated from the Eemian zone $\mathrm{E}$ by glacial deposits (zone F), it could as well belong to an early part of the Eemian Interglacial. It should be pointed out that the foraminiferal faunas of Anholt 1 also resemble faunas from the so-called $\mathrm{Ru}$ gen Interglacial, which has been referred to the upper part of the Saalian Glacial period (Wiegank 1972). This interglacial is, however, controversial and perhaps identic with the Eemian Interglacial.

Zone $\mathrm{G}$ corresponds to part of series IV of Nørvang (Gry et al. 1944). Nørvang could not make out whether this zone was marine or fluvial.

Nordmann concluded from the presence of mollusc fragments that one of the nine examined samples from this interval might be marine.

\section{Zone H}

The sediments contain only very few Foraminifera between 125 and $151 \mathrm{~m}$. This sequence is called zone $\mathrm{H}$ and it includes coarse grained quartz-sand with some stones, shell-fragments and pieces of coal. 
In the lowermost part of the zone there are two intervals with sandy clay. Only ditch samples were available from this zone (fig. 9).

Elphidium excavatum, Bulimina marginata and Hyalinea balthica dominate these very sparse faunas. All the species found are also present in the overlying zone. Therefore it cannot be excluded that the Foraminifera in zone $\mathrm{H}$ were washed down during drilling.

On account of this, zone $\mathrm{H}$ is considered to include glacial deposits. The composition of the sediments suggests that these have been derived from erosion of the Jurassic sediments which are exposed in the region south-east of Anholt (Liboriussen et al. 1987). The zone may represent a stadial in the Saalian Glacial period.

Nørvang also included this part of the boring in his series IV (Gry et al. 1944).

Nordmann examined three samples from this zone, but he did not comment on the mollusc fragments found.

\section{Zone I}

Zone I (151-170.7 $\mathrm{m}$ ) consists of stony and clayey, coarse to medium sands with shellfragments and small pieces of coal.

Foraminifera are present in rather large numbers in most of the samples. Only one sample was taken from the drilling bit and it contained more than 2000 specimens in 100 g sediment.

Elphidium excavatum dominates the faunas and Cassidulina reniforme is also important. In addition Bulimina marginata, Buccella frigida, Nonion labradoricum, Elphidium albiumbilicatum, Hyalinea balthica, Nonion orbiculare and Cassidulina laevigata are all common (fig. 9).

The faunal composition of sample no. 192 $(15 \mathrm{~g})$ is shown as an example.

\begin{tabular}{|c|c|c|}
\hline Species & Frequency & Percentage \\
\hline Elphidium excavatum & 141 & 46 \\
\hline Cassidulina reniforme & 46 & 15 \\
\hline Bulimina marginata & 25 & 8 \\
\hline Buccella frigida & 15 & 5 \\
\hline Nonion labradoricum & 14 & 5 \\
\hline Hyalinea balthica & 11 & 4 \\
\hline Elphidium albiumbilicatum & 11 & 4 \\
\hline Nonion orbiculare & 9 & 3 \\
\hline Cassidulina laevigata & 7 & 2 \\
\hline Islandiella norcrossi & 5 & 2 \\
\hline Angulogerina fluens & 4 & 1 \\
\hline Islandiella helenae & 2 & 1 \\
\hline Nonion depressulum & 2 & 1 \\
\hline Astrononion gallowayi & 2 & 1 \\
\hline Elphidium bartletti & 2 & 1 \\
\hline Textularia sagittula & 1 & $<0.5$ \\
\hline \multicolumn{3}{|l|}{ Quinqueloculina semi- } \\
\hline nulum & 1 & $<0.5$ \\
\hline Buliminella elegantissima & 1 & $<0.5$ \\
\hline Stainforthia loeblichi & 1 & $<0.5$ \\
\hline Angulogerina angulosa & 1 & $<0.5$ \\
\hline Nonion niveum & 1 & $<0.5$ \\
\hline Elphidium groenlandicum & 1 & $<0.5$ \\
\hline Elphidium hallandense & 1 & $<0.5$ \\
\hline Ammonia batava & 1 & $<0.5$ \\
\hline Total & 305 & \\
\hline
\end{tabular}

There would appear an overrepresentation of Bulimina marginata and other boreal taxa in the ditch samples, possibly due to downcore contamination.

The foraminiferal fauna in the sample from the drilling bit indicates marine subarctic shallow water conditions with water depths of 20 to $50 \mathrm{~m}$.

Zone $I$ is referred to an interstadial period called Anholt 2 and it is placed in the Saalian Glacial period.

This zone was included in series IV by Nørvang (Gry et al. 1944).

Nordmann studied the molluscs in one sample from this zone, but he did not report what he found. 


\section{Zone J}

Only very few Foraminifera are present in the interval between 170.7 and $192.25 \mathrm{~m}$ (fig. 9). The sediments here consist of compact stony clays with comminuted shell material and coal underlain by thin layers of sand, clay and sandy clay with stones.

The core samples from zone $J$ did not contain any Foraminifera. Bulimina marginata, Elphidium excavatum, Hyalinea balthica and Cassidulina laevigata are the most common taxa in the ditch samples. All the species found also occur in the overlying layers, an indication of possible contamination during drilling. Due to the type of sediment and the sparsity of Foraminifera, this zone is regarded as a glacial till. It is not possible to date this glacial event, but on the basis of its location in the boring it is referred to a Saalian Stadial period (fig. 9).

Nørvang examined one sample from this interval but found no Foraminifera.

\section{Zone $\mathbf{K}$}

The lowermost part of the boring (192.25$228.81 \mathrm{~m}$ ) contains several sedimental facies. Stony, medium to coarse grained sands with shells occur in the upper $14 \mathrm{~m}$. These sands are underlain by stony clays with two thin layers of sand. Near the bottom layers of sticky clay, sand, stony sand with shellfragments and stony clays occur (fig. 9).

Core samples, samples extracted from the drilling bit and ditch samples are all available from this section of the boring and they all contain Foraminifera.

Elphidium excavatum dominates the faunas together with Cassidulina reniforme and Bulimina marginata. Nonion labradoricum, N. orbiculare, Buccella frigida, Elphidium albiumbilicatum, Cassidulina laevigata, Hyalinea balthica, Epistominella vitrea and Islandiella helenae are also common. As already mentioned there is a clear difference between the faunal composition of the different types of samples, as the content of
Bulimina marginata and other boreal forms is overrepresented in the ditch samples. Therefore the interpretation of the foraminiferal assemblages is also here based only on the core samples and the samples from the drilling bit.

An example of the assemblage of zone $\mathrm{K}$ (sample no. 251b) is presented below; the foraminiferal content of half of the sample $(100 \mathrm{~g})$ was counted:

\begin{tabular}{|c|c|c|}
\hline Species & Frequency & Percentage \\
\hline Elphidium excavatum & 123 & 39 \\
\hline Bulimina marginata & 47 & 15 \\
\hline Cassidulina reniforme & 41 & 13 \\
\hline Buccella frigida & 14 & 5 \\
\hline Cassidulina laevigata & 13 & 4 \\
\hline Nonion orbiculare & 13 & 4 \\
\hline Hyalinea balthica & 10 & 3 \\
\hline Elphidium albiumbilicatum & 9 & 3 \\
\hline Nonion labradoricum & 7 & 2 \\
\hline Elphidium bartletti & 6 & 2 \\
\hline Epistominella vitrea & 4 & 1 \\
\hline Fissurina danica & 3 & 1 \\
\hline Stainforthia schreibersiana & 3 & 1 \\
\hline Islandiella helenae & 2 & 1 \\
\hline Islandiella islandica & 2 & 1 \\
\hline Planulina ariminensis & 2 & 1 \\
\hline Nonionella iridea & 2 & 1 \\
\hline Ammonia batava & 2 & 1 \\
\hline Dentalina sp. & 1 & $<0.5$ \\
\hline Lagena striata & 1 & $<0.5$ \\
\hline Guttulina austriaca & 1 & $<0.5$ \\
\hline Fissurina laevigata & 1 & $<0.5$ \\
\hline Stainforthia loeblichi & 1 & $<0.5$ \\
\hline Uvigerina peregrina & 1 & $<0.5$ \\
\hline Angulogerina fluens & 1 & $<0.5$ \\
\hline Islandiella norcrossi & 1 & $<0.5$ \\
\hline Cibicides lobatulus & 1 & $<0.5$ \\
\hline Elphidium asklundi & 1 & $<0.5$ \\
\hline Elphidium macellum & 1 & $<0.5$ \\
\hline Total & 314 & \\
\hline
\end{tabular}

The foraminiferal faunas of zone $\mathrm{K}$ indicate a marine boreal-arctic to arctic environment with moderate water depths, suggesting an interstadial period. This interstadial is here called Anholt 3, and it is placed in the Saalian Glaciation due to the lack of contrary evidence for placing it in an older glacial period. 
The Hesselø boring (Geol. Surv. file no. $180.1)$ in the southern part of Kattegat contains $47 \mathrm{~m}$ of Quaternary deposits. Here the lowermost sample, which was extracted from stony clays containing shell-fragments, contains a foraminiferal assemblage which can be correlated with zone $\mathrm{K}$ on Anholt.

The Saalian zone 8c, the lower part of the Epistominella vitrea-Nonion labradoricum Zone, at the base of the Nørre Lyngby boring in Vendsyssel also contains this fauna (Lykke-Andersen 1987).

The whole sequence in the Anholt boring from 85.7 to $228.81 \mathrm{~m}$ has consequently been placed in the Saalian (sensu lato).
Nørvang looked at the foraminiferal faunas in part of zone $K$ and found a mixed fauna, with the main emphasis being placed on arctic species. He called this part of the boring series V (fig. 8).

The molluses from the same interval were not described.

Gry concluded that the main part of the sequence from 77.2 to $228.81 \mathrm{~m}$ consisted of glaciofluvial and till deposits but with possible interglacial layers near the bottom corresponding to series $\mathrm{V}$ of Nørvang (see above). 


\section{Conclusions}

The $228.81 \mathrm{~m}$ deep boring at Anholt contains a Quaternary sequence representing in all probability the timespan from the Saalian to the Holocene. The main part of the deposits, from 228.81 to $85.7 \mathrm{~m}$, are preEemian, and they seem to belong to the Saalian (sensu lato). The very crude stratigraphic classification presented here, which is a function of the relatively bad condition of the samples, indicates the existence of at least three marine periods during the Saalian, interrupted by glacial periods (fig. 9). These are called Anholt 1,2 and 3 and are interpreted as representing interstadials due to the composition of their foraminiferal faunas. Temperature and water depth seem to have been at a maximum during Anholt 1.

The non-marine interval between Anholt 3 and 2 contains an about $20 \mathrm{~m}$ thick clayey till with some glaciofluvial layers near the bottom. About $30 \mathrm{~m}$ of glaciofluvial sand with some clay occur between Anholt 2 and 1 , and 2 metres of sandy till or glaciofluvial sandy gravel rich in bryozoans are found on top of Anholt 1.

Eemian Interglacial deposits occur between 85.7 and $72.7 \mathrm{~m}$ (fig. 9). The foraminiferal assemblages indicate increasing temperatures and water depths upwards, both decreasing again near the top of the interval.

The sequence from 72.7 to $3.0 \mathrm{~m}$ is referred to the Weichselian (fig. 9). The Early Weichselian and the lower part of Middle Weichselian are not present. The foraminiferal faunas found in these sediments indicate a marine arctic shallow water environment and they correspond to faunas belonging to the Middle Weichselian Vennebjerg Stadial (Lykke-Andersen \&
Knudsen 1990). These are succeeded by another marine unit containing an arctic fauna with a boreal element which can be correlated with faunas from the Middle Weichselian Sandnes Interstadial (Feyling-Hanssen et al. 1971). The Middle Weichselian marine deposits are covered by sediments which are presumed to be of glacial origin. These seem to include three tills and some glaciofluvial sediments, and they are referred to the Late Weichselian. No marine Late Weichselian layers have been recognized.

Holocene marine shallow water deposits form the top $3 \mathrm{~m}$ of the Quaternary sequence (fig. 9).

The Quaternary sequence present in the Anholt boring is comparable with sequences found in a number of borings in the Vendsyssel-Kattegat region (Jessen et al. 1910; Bahnson et al. 1974; Knudsen \& LykkeAndersen 1982; Knudsen 1984, 1985, 1986; Lykke-Andersen 1987; Lykke-Andersen \& Knudsen 1990). The sequence in Anholt differs from most of the borings in the region primarily because of its thick pre-Eemian and thin Eemian interval. Another difference is the greater number of tills and glaciofluvial sediments in the Anholt boring. The thickness of the pre-Eemian deposits suggest a basin located in the southern part of the region prior to the Eemian Interglacial. The Eemian and the Weichselian deposits thicken to the northeast indicating that the depocentre has moved to the north during these periods. Comparable thick Saalian sequences are known in the buried valleys of Germany (e. g. Ehlers et al. 1984) and in the British sector of the North Sea (Cameron et al 1987). 


\section{Foraminiferal list}

The species shown in the range chart (fig. 9) and mentioned in the text are arranged alphabetically in the following list. A total of at least 80 species were found, 17 of which are illustrated in Plates 1 and 2.

Ammonia batava (Hofker 1951)

Amphicoryna scalaris (Batsch 1791) Angulogerina angulosa (Williamson 1858) Angulogerina fluens Todd 1947

Anomalina globulosa Chapman \& Parr 1937

Astrononion gallowayi Loeblich \& Tappan 1953

Bolivina subspinescens Cushman 1922

Bolivina cf. robusta Brady

Buccella frigida (Cushman 1922)

Buccella tenerrima (Bandy 1950)

Bulimina marginata d 'Orbigny 1826

Buliminella elegantissima (d 'Orbigny 1839)

Cassidulina laevigata d 'Orbigny 1826

Cassidulina reniforme Nørvang 1945

Cibicides lobatulus (Walker \& Jacob 1798)

Elphidium albiumbilicatum (Weiss 1954)

Elphidium asklundi Brotzen 1943

Elphidium bartletti Cushman 1933

Elphidium excavatum (Terquem 1876)

Elphidium groenlandicum Cushman 1933

Elphidium hallandense Brotzen 1943

Elphidium macellum (Fichtel \& Moll 1798)

Elphidium williamsoni Haynes 1973

Epistominella takayanagii Iwasa 1955

Epistominella vitrea Parker 1953

Fissurina danica (Madsen 1895)

Fissurina laevigata Reuss 1850

Globobulimina auriculata arctica Höglund 1947

Globobulimina turgida (Bailey 1851)
Guttulina austriaca d 'Orbigny 1846

Guttulina lactea (Walker \& Jacob 1798)

Hyalinea balthica (Schroeter 1783)

Islandiella helenae Feyling-Hanssen \&

Buzas 1976

Islandiella islandica (Nørvang 1945)

Islandiella norcrossi (Cushman 1933)

Lagena distoma Parker \& Jones 1864

Lagena striata (d 'Orbigny 1839)

Lagena sulcata laevicostata Cushman \& Gray 1946

Miliolinella subrotunda (Montagu 1784)

Nonion barleeanum (Williamson 1858)

Nonion depressulum (Walker \& Jacob 1798)

Nonion labradoricum (Dawson 1960)

Nonion niveum Lafrenz 1963

Nonion orbiculare (Brady 1881)

Nonionella iridea Heron-Allen \& Earland 1932

Nonionella turgida (Williamson 1858)

Parafissurina himatiostoma Loeblich \& Tappan 1953

Parafissurina lateralis (Cushman), forma carinata (Buchner 1940)

Planulina ariminensis d 'Orbigny 1826

Pullenia osloensis Feyling-Hanssen 1954

Pyrgo williamsoni (Silvestri 1858)

Quinqueloculina padana Perconig 1954

Quinqueloculina seminulum (Linné 1758)

Sigmoilopsis schlumbergeri (Silvestri 1904)

Spiroloculina rotunda d'Orbigny 1826

Stainforthia fusiformis (Williamson 1858)

Stainforthia loeblichi (Feyling-Hanssen 1954)

Stainforthia schreibersiana (Czjzek 1848)

Textularia sagittula Defrance 1824

Uvigerina peregrina Cushman 1923 


\section{Acknowledgements}

I am grateful to the Geological Survey of Denmark for placing material from the Anholt boring no. 51.12 at my disposal. In that connection I owe special thanks to Niels V. Jessen for unremitting help and interest in my work. My sincere thanks to Karen Luise Knudsen and Holger Lykke-Andersen for valuable discussions about the stratigraphy and to David N. Penney for improving the English text. I would also like to thank Jette Gissel Nielsen for making the drawings and Hans Jørgen Hansen for preparing the scanning electron micrographs. 


\section{Dansk sammendrag}

\section{Foraminifer-stratigrafisk inddeling af kvartare aflejringer $i$ boring nr. 51.12, Anholt}

En 229 meter dyb boring (D.G.U. nr. 51.12) blev udført på Anholt i 1943 (fig. 1, $2,3,4,5,6 \circ \mathrm{og}$ ). Borearbejdet blev udført af "Produktionsaktieselskabet Undergrunden, Aarhus". For Danmarks Geologiske Undersøgelse varetog Helge Gry den geologiske ledelse af boringen, og Axel Nørvang var geologisk tilsynsførende på borestedet. Boringen og dens geologiske resultater er beskrevet i Danmarks Geologiske Undersøgelses interne rapporter (Gry et al. 1944; Hansen 1944). Gry beskrev de geologiske forhold, Nordmann unders $ø$ gte molluskindholdet i nogle udvalgte prøver og Nørvang analyserede foraminifer-faunaerne. Nørvang beskrev desuden borearbejdets gang og Sigurd Hansen gjorde rede for de økonomiske forhold. Da de geologiske resultater af disse undersøgelser ikke er publiceret, gives her en ret udførlig gennemgang deraf.

Formålet med boringen var at undersøge de geologiske forhold med henblik på forekomster af anvendelige råstoffer specielt kul. Det havde længe været kendt, at der skyllede kul op på Anholts kyster, men man vidste ikke, om disse kul stammede fra tertiære lag fra havbunden i nærheden af Anholt, eller om det var Rhät-Lias kul af samme type, som i forekomsterne i Skåne og på Bornholm. Det ansås for sandsynligt, at Kullen-horsten med dens kulførende aflejringer fortsatte $\mathrm{i}$ nordvestlig retning til Anholt.

Boringen blev udført som Rotary-boring med henblik på at få kerneprøver gennem hele boreprofilet. De stenede aflejringer bevirkede, at borearbejdet flere gange gik $\mathrm{i}$ stå, enten fordi det var nødvendigt at foretage sprængninger, eller fordi grejet gik $i$ stykker. Desværre satte forerørene sig fast $i$ 34,48 meters dybde, hvilket bevirkede, at størsteparten af boringen blev udført uden foring. Dette besværliggjorde kernetagningen og forårsagede, at en stor del af prøverne, især de mange skylle-og sigteprøver, må formodes at være forurenede af materiale fra overliggende lag. Borehullet skred sammen flere gange under arbejdet, og skyllevandet forsvandt ud i nogle af de gennemborede lag. Under fors $\emptyset \mathrm{g}$ på at stoppe disse lækager slap det medbragte ler op. Der er derfor anvendt postglacialt ler fra Anholt som skyllemudder fra $210 \mathrm{~m}$ og nedefter. Da boringen havde nået en dybde af 228,81 m knækkede borestammen, og borearbejdet blev indstillet efter en række forgæves forsøg på at fiske borestammen op igen.

Der blev ialt taget 10 meget korte kerner, hvoraf den $\varnothing$ verste $(13,9-16,7 \mathrm{~m})$ ikke kunne anvendes, idet kernetageren kun indeholdt nedfaldet materiale (Gry et al. 1944), 24 mejselprøver og 219 skylle- og sigteprøver.

Nordmann unders $\emptyset$ gte molluskindholdet i 22 prøver fra en dybde af $62,7 \mathrm{~m}$ og nedefter. Ud fra skallernes bevaringstilstand mente han, at intervallet fra 62,7 til $70,7 \mathrm{~m}$ var marint, og at intervallerne $73,7-76 \mathrm{~m} \mathrm{og}$ 103-105 m muligvis også var marine (fig. 8). Han kunne ikke konstatere, om de andre prøver var marine eller glacigene $\mathrm{i}$ deres oprindelse. Nordmann karakteriserede faunaen således: “... vi har at gøre med en boreal Fauna med et vist sydligt Præg, saa- 
ledes at man ikke med Bestemthed kan henføre den til nogen af de kendte interglaciale faunaer, hverken til den lusitanske Eemfauna eller til Skærumhedefaunaen. Den synes nærmest at slutte sig til SkærumhedeSeriens nederste boreale, forholdsvis varme Zone (Turritella terebra-Zonen), men har dog paa Grund af Tilstedeværelsen af den lusitanske Form Lucina divaricata et endnu sydligere Præg".

Nordmann gjorde desuden opmærksom på, at der i de øvrige prøver ikke med sikkerhed kunne påvises højarktiske arter.

Nørvang analyserede foraminifer-faunaerne i 28 prøver, heraf 17 mejselprøver. Han inddelte lagserien i fem serier, I-V (fig. $8)$. Serie I $(13,9-70,7 \mathrm{~m})$ indeholdt en sparsom fauna, præget af arktiske arter. Nørvang fandt det vanskeligt at afgøre, om serien var af marin eller fluviatil oprindelse.

Serie II $(73,7-79,7 \mathrm{~m})$ var kendetegnet af et stort antal foraminiferer, som bestod af en rakke arter, som ikke lever under arktiske forhold. Han karakteriserede denne del af lagserien som marin med en fauna af en sydlig boreal karakter. Nørvang fandt dog i de $\emptyset$ verste prøver i denne serie nogle former fra køligere områder.

Serie III $(79,7-85,7 \mathrm{~m})$ omfattede kun to sigteprøver. Foraminifer-faunaen karakteriseredes her af, at boreale arter går tilbage og erstattes af former, som lever i køligere områder. Nørvang opstillede tre mulige årsager til oprindelsen af denne fauna. 1: Faunaen i serie III svarede til faunaen i serie II, som under borearbejdet var blevet forurenet med faunaen i serie I. 2: Faunaen i serie III var en ren arktisk fauna, som under borearbejdet var blevet forurenet med faunaen fra serie II, 3: De arktiske eller de boreale foraminiferer eller begge var sekundære; serie III var fx en lokal till bestående af forskellige marine lag. De tre muligheder diskuteredes, og Nørvang hældede mest til den antagelse, at serie III indeholdt stenet ishavsler med en arktisk fauna, som var forurenet af materiale fra serie II eller, at serie II var en lokal till. Han påpegede tilstede- værelsen af et arktisk faunaelement ældre end lagene $i$ den boreale serie II.

Serie IV (109,7-157,7 $\mathrm{m}$ ) havde et ringe indhold af foraminiferer. Nørvang fandt det derfor vanskeligt at afgøre, om denne serie var marin.

Serie V (215,8-224,7 m) indeholdt igen en blandingsfauna med både arktiske og boreale arter. Nørvang påpegede, at de fleste arter var arktiske.

Nørvang fors $\emptyset$ gte ikke at indplacere disse serier $\mathrm{i}$ de dengang kendte istider og mellemistider.

Gry opstillede som et foreløbigt resultat af undersøgelserne følgende lagserie (se også fig. 8):

0 - 3,0 m marint, postglacialt sand og strandgrus

$3,0-56,5 \mathrm{~m}$ sandsynligvis overvejende fluvioglaciale dannelser og till (måske med marint arktisk ler fra 43,7 til 45,2 m)

56,5 - 77,2 m marint, borealt interglacialt (sammenlignes med Skærumhede Seriens Turritella terebra Zone)

77,2 - 228,8 m overvejende fluvioglaciale dannelser og moræne sandsynligvis med interglaciale lag forneden.

Selv om de kvartære aflejringer under Anholt ikke blev gennemboret, gav boringen en række værdifulde geologiske resultater. Gry konstaterede, at Anholt ikke lå i et horstområde, og at der derfor ikke fandtes kulførende Rhät-Lias dannelser i opnåelig dybde under øen. Prækvartæroverfladens dybe beliggenhed under Anholt blev forklaret enten som et resultat af iserosion eller af tektoniske bevægelser langs brudlinier. Gry fandt det sandsynligt, at den gravsænkning, som var fundet under Alnarp-Dalen i Skåne, fortsatte mod nordvest gennem Kattegat til Anholt, og at den havde spillet en rolle for Skærumhedehavets transgression. 
Mörner (1969) tolkede aflejringerne i boringen på Anholt således:

A: Til 72,7 m en $\emptyset v r e$ glacigen serie ("drift series") $=\varnothing v$ re Pleniglacial (i Holland).

B: Til $77,2 \mathrm{~m}$ marint ler $=$ en del af Portlandia arctica Zonen $(57,4-74,4 \mathrm{~m}) \mathrm{i}$ Skærumhede I boringen og Interpleniglacial i Holland.

C: Til $228,81 \mathrm{~m}$ en nedre glacigen serie ("drift series") = Nedre Pleniglacial (i Holland).

Den nedre glacigene serie blev anset for at indeholde sedimenter, som var akkumuleret foran isfronten under det "Gammelbaltiske isfremst $\varnothing \mathrm{d} "$ i Weichsel (ca. 50.000 B.P.). Mörner antog, at isen i denne periode dækkede den $\emptyset$ stlige og sydlige del af Kattegat og at den, under dens maximale udbredelse, nåede til en linie fra Djursland til et område $\emptyset$ st for Anholt og derfra videre mod nord til et område $\emptyset$ st for Læs $\emptyset$. Som et lokalt navn for dette fremst $\varnothing \mathrm{d}$ blev Anholt Stadial foreslået.

Formålet med den her foreliggende undersøgelse har været at foretage en foraminifer-stratigrafisk inddeling af de kvartære aflejringer $\mathrm{i}$ boringen. Lagserien, som indeholder både marine og ikke-marine glacigene sedimenter, er inddelt $i$ elleve zoner, zone A til zone K (fig. 9). Disse zoner omfatter aflejringer fra Holocen til præ-Eem, rimeligvis Saale (sensu lato).

\section{Holocen}

Den øverste del af lagserien $(0-3 \mathrm{~m})$ består af marint sand og grus med skaller, zone $\mathrm{A}$. Desværre er de fleste foraminiferer udvaskede eller fyldt med pyrit. De bestemmelige arter, sedimentets karakter og beliggenhed i lagserien peger på, at aflejringen er Holocen.

\section{Weichsel}

Zone B (3-34 m) omfatter sedimenter af forskellig karakter, som næsten alle indeholder foraminiferer. Et relativt stort indhold af prækvartære former i flere af prøverne tyder dog på, at materialet kan være omlejret. De stenede og sandede lersedimenter $(20,1-21,7 \mathrm{~m}, 22,3-23,3 \mathrm{~m}$ og 25-26, $55 \mathrm{~m}$ ) betragtes derfor som till-aflejringer, og lagene imellem disse som glaciofluviale. Der er ikke fundet senglaciale marine lag, hvilket sikkert skyldes en række boretekniske problemer netop under denne del af borearbejdet (se ovenfor). Zone B er henført til Sen Weichsel (fig. 9).

Zone C (34-43 $\mathrm{m}$ ) består af lersedimenter med sten og skaller. Foraminifer-indholdet $\mathrm{i}$ disse lag tyder på, at aflejringen er marin. Faunaerne afspejler moderate vanddybder og arktiske til boreo-arktiske klimatiske betingelser. Tilsvarende faunaer er kendt fra Sandnes Interstadial (Feyling-Hanssen et al. 1971) i Vendsyssel-Kattegat området (Lykke-Andersen 1987).

Zone D (43-72,7 m) indeholder øverst de samme lersedimenter som zone $C$. Derunder findes sand med mange skalfragmenter. Disse lag indeholder en arktisk lavtvandsfauna, som kan korreleres med faunaer fundet i Vendsyssel-Kattegat området fra Vennebjerg Stadial perioden (Lykke-Andersen \& Knudsen 1990).

Zonerne $\mathrm{C}$ og $\mathrm{D}$ er således henført til den $\emptyset$ vre del af Mellem Weichsel (fig. 9).

Aflejringer fra den nedre del af Mellem Weichsel og Tidlig Weichsel er ikke antruffet her.

\section{Eem}

En tydelig ændring af både sedimenttype og foraminifer-faunaernes sammensætning markerer overgangen til zone $\mathrm{E}(72,7-83,7$ m). Sedimentet består af grønligt, fedt ler, underlejret af skiftende lag af sand og ler. Alle lagene indeholder skaller af mollusker (fig. 9). Foraminifer-faunaerne i disse lag er 
domineret af boreale arter og i en del af serien forekommer også boreo-lusitanske former. Hovedparten af faunaerne stammer fra havområder, hvor temperaturen har været lidt højere end i det nuværende Kattegat og vanddybden $50-100 \mathrm{~m}$. I den allerøverste del af zone $\mathrm{E}$ tyder fauna-sammensætningen på, at både temperatur og vanddybde bliver lavere. De nederste prøver, som stammer fra de sandede sedimenter, indeholder en del arter fra arktiske lavtvandsområder. Disse prøver, som er skylleprøver, kan være forurenede af nedskyllet materiale.

Størstedelen af foraminifer-faunaerne i zone $\mathrm{E}$ udviser stor lighed med faunaer fra den nedre del af Turritella terebra Zonen i Skærumhede Serien (Jessen et al. 1910). Tilsvarende faunaer er kendt $i$ dele af Vendsyssel-Kattegat området, og de er henført til Eem (Feyling-Hanssen et al. 1971; Knudsen \& Lykke-Andersen 1982; Knudsen 1984, 1985; Lykke-Andersen 1987; Lykke-Andersen \& Knudsen 1990). Aminosyre målinger på foraminiferer fra zone $\mathrm{E} i$ Anholt bekræfter denne antagelse (Knudsen \& Sejrup 1988).

\section{Præ-Eem}

Zone $\mathrm{F}(85,7-87,9 \mathrm{~m})$ består af stenholdigt sand med ret store mængder bryozoer. Kerneprøver fra denne aflejring indeholdt kun prækvartære foraminiferer. Det må derfor antages, at sedimentet er till-sand eller glaciofluvialt sand. Som følge af beliggenheden i lagserien er zone F placeret i Saale (fig. 9). Det skal bemærkes, at der findes et tilsvarende sediment under Eemet i Skærumhede I boringen (Jessen et al. 1910).

Vekslende tynde sand- og lerlag med skalfragmenter er indeholdt i zone $\mathrm{G}(87,9-$ $125 \mathrm{~m}$ ). Da alle prøver $\mathrm{i}$ denne zone indeholder foraminiferer, formodes den at være marin. Der er dog en tydelig nedvaskning af arter især fra Eemlagene, og det er derfor vanskeligt at vurdere, hvorledes den oprindelige fauna-sammensætning har været. Mejselprøverne indeholder faunaer fra boreale til boreo-arktiske marin-klimatiske miljøer, hvor havdybden har været moderat. Hvis disse faunaer er oprindelig hjemmehørende i sedimentet, må det stamme fra en interstadial periode. Zone $G$ er i diagrammet (fig 9) kaldt Anholt $1 \mathrm{og}$ henført til Saale.

En aflejring af grov- til mellemkornet kvartssand med et par sandede lerlag nær bunden underlejrer zone G. Sandet, som indeholder en del kulstykker og nogle få skalfragmenter, stammer rimeligvis fra erosion af jurassiske sedimenter, som er blottet på havbunden sydøst for Anholt (Liboriussen et al. 1987). Der er fundet ganske få kvartære foraminiferer i denne zone, som er kaldt H (125-151 m). Materialet i zone $\mathrm{H}$ er tolket som glaciofluvialt tilhørende en stadial periode i Saale (fig. 9).

Prøver fra zone I (151-170,7 m) indeholder igen foraminiferer, især i den øverste del af zonen er antallet stort. Der er dog desværre kun én mejselprøve fra dette interval. Faunaen i denne prøve afspejler et marint subarktisk lavtvandsområde. Dette st $\varnothing t t e s$ af foraminifer-indholdet $\mathrm{i}$ de omgivende skylle- og sigteprøver, selv om de tydeligvis er forurenede af materiale ovenfra. Zone I er henført til en interglacial periode i Saale, kaldet Anholt 2 (fig. 9).

Størstedelen af zone J (170,7-192,25 m) består af ret fedt stenet ler med kulstykker og små skalfragmenter. Nær bunden findes tynde lag af sand og ler. Kerneprøver herfra indeholder ikke foraminiferer og i de $\emptyset$ vrige prøver, er der kun fundet få. Hovedparten af zone $\mathbf{J}$ kan være en till-aflejring. Det er ikke muligt at datere zonen, men den er ud fra placeringen $\mathrm{i}$ boringen henført til en Saale Stadial (fig. 9).

Den nederste del af lagserien, zone $\mathrm{K}$ $(192,25-228,81 \mathrm{~m})$, indeholder en rakke forskellige sedimenter. Stenholdige mellemtil grovkornede sandlag med molluskskaller overlejrer stenet ler med tynde sandlag. Derunder findes forskellige ler og sandlag igen med sten og skaller. Alle prøver fra dette interval indeholder foraminiferer, dog i varierende mængde (fig. 9). Det formodes, 
at dele af denne lagserie er marine, og der kan være tale om flere marine perioder. Det prøvemateriale, som er til rådighed, tillader imidlertid ikke en opdeling. Zone $\mathrm{K}$ indeholder boreal-arktiske til arktiske foraminifer-faunaer fra moderate vanddybder. Sådanne faunaer må karakteriseres som interstadiale. Perioden er her kaldt Anholt 3 og placeret i Saale, da der ikke er arter i faunaen, som peger på en ældre glacial periode. Tilsvarende foraminifer-faunaer er fundet $\mathrm{i}$ den nederste del af den kvartære lagserie i en boring på Hesselø (DGU 180.1), og Nørre Lyngbyboringen (LykkeAndersen 1987) indeholdt lignende faunaer $i$ bunden af den kvartære serie.

Hele præ-Eem lagserien (85,7-228,81 m) er således placeret i Saale (sensu lato).

Den 229 m mægtige kvartære lagserie i boring $\mathrm{nr} .51 .12$ på Anholt synes nederst at bestå af aflejringer fra Saale Istiden, som indeholder mindst tre marine interstadialer, kaldet Anholt 1, 2 og 3, hvoraf Anholt 1 er den varmeste. Glacigene materialer mellemlejrer de marine afsnit. Over Saale-forekomsterne findes marine lag fra Eem Mellemistiden, svarende til den nedre del af Skærumhede Seriens Turritella terebra Zone. Tidlig Weichsel og den nedre del af Mellem Weichsel mangler. Øvre Mellem Weichsel er repræsenteret af marine sedimenter fra Vennebjerg Stadial og Sandnes Interstadial, svarende til en del af Portlandia arctica Zonen i Skærumhede Serien. Derover forekommer lag, som tilsyneladende er glacigene og derfor henført til Sen Weichsel. Marine senglaciale aflejringer er ikke fundet, rimeligvis p.g.a. et mangelfuldt prøvemateriale fra denne del af boringen. Holocene marine dannelser afslutter lagserien. 


\section{References}

Bahnson, H., Petersen, K. S., Konradi, P. B. \& Knudsen, K. L., 1974: Stratigraphy of Quaternary deposits in the Skærumhede II boring: lithology, molluscs and foraminifera. Danmarks Geologiske Undersøgelse, Årbog 1973, 27-62.

Bergström, J., Holland, B., Larsson, K., Norling, E. \& Sivhed, U., 1982: Guide to excursions in Scania. Sveriges Geologiska Undersökning Serie C, 54, 1-95.

Cameron, T. D. J., Stoker, M. S. \& Long, D., 1987: The history of Quaternary sedimentation in the UK sector of the North Sea Basin. Journal of the Geological Society London, 144, 43-58.

Ehlers, J., Meyer, K. -D. \& Stephan, H. - J., 1984: The Pre-Weichselian glaciations of North West Europe. Quaternary Science Reviews, 3, 1-40.

Feyling-Hanssen, R. W., 1971: Weichselian interstadial Foraminifera from the Sandnes-Jæren area. Bulletin of the Geological Society of Denmark 21, $72-116$

Feyling-Hanssen, R. W., Jørgensen, J. A., Knudsen, K. L. \& Lykke-Andersen, A. -L., 1971: Late Quaternary Foraminifera from Vendsyssel, Denmark and Sandnes, Norway. Bulletin of the Geological Society of Denmark 21 (2-3), 67-317

Gry, H., Nordmann, V. \& Nørvang, A., 1944: Geologisk Rapport over Boring Nr. 51.12, Anholt. Danmarks Geologiske Undersøgelse. (Unpublished Report).

Hansen, S., 1944: Rapport om Anholtboringen 1943 (Nr. 51.12). Danmarks Geologiske Undersøgelse. (Unpublished Report).

Jessen, A., Milthers, V., Nordmann, V., Hartz, N. \& Hesselbo, A., 1910: En Boring gennem de kvartære Lag ved Skærumhede. Danmarks Geologiske Undersøgelse, II Række, 25, 1-175.

Knudsen, K. L., 1984: Foraminiferal stratigraphy in a marine Eemian-Weichselian sequence at Apholm, North Jutland. Bulletin of the Geological Society of Denmark 32, 169-180.

Knudsen, K. L., 1985: Correlation of Saalian, Eemian and Weichselian foraminiferal zones in North Jutland. Bulletin of the Geological Society of Denmark 33, 325-339.

Knudsen, K. L., 1986: Foraminiferstratigrafisk undersøgelse af marint Weichsel på Læsø. Danmarks Geologiske Undersøgelse, serie D, 6, 29-46.

Knudsen, K. L. \& Lykke-Andersen, A. -L., 1982: Foraminifera in Late Saalian, Eemian, Early and
Middle Weichselian of the Skærumhede I boring. Bulletin of the Geological Society of Denmark 30, 97-109.

Knudsen, K. L. \& Sejrup, H. P., 1988: Amino acid geochronology of selected interglacial sites in the North Sea area. Boreas 17, 347-354.

Konradi, P. B. \& Knudsen, K. L., 1974: Foraminifera in the Skærumhede II boring. Danmarks Geologiske Undersøgelse, Årbog 1973, 43-57.

Liboriussen, J., Ashton, P. \& Tygesen, T., 1987: The tectonic evolution of the Fennoscandian Border Zone in Denmark. In: P A. Ziegler (ed.), Compressional Intra-Plate Deformations in the Alpine Foreland. Tectonophysics. 137: 21-29.

Lykke-Andersen, A. -L., 1971: Foraminifera from the Older Yoldia Clay in Hirtshals. Bulletin of the Geological Society of Denmark 21, 159-184.

Lykke-Andersen, A. -L., 1982: Nogle nye C-14 dateringer fra Ældre Yoldia Ler i Hirtshals kystklint. Dansk Geologisk Forening, Årsskrift for 1981, 119-121.

Lykke-Andersen, A. -L., 1987: A Late Saalian, Eemian and Weichselian marine sequence at Nørre Lyngby, Vendsyssel, Denmark. Boreas 16, 345357.

Lykke-Andersen, A. -L. \& Knudsen, K. L., 1990 Saalian, Eemian, and Weichselian in the Vendsyssel-Kattegat Region, Denmark. Striae, in press.

Mangerud, J. \& Berglund, B. E., 1978: The subdivision of the Quaternary of Norden: a discussion. Boreas 7, 179-181.

Meldgaard, S. \& Knudsen, K. L., 1979: Metoder til indsamling og oparbejdning af prøver til foraminiferanalyser. Dansk Natur - Dansk Skole, Årsskrift 1979, 48-57.

Mörner, N. -A., 1969: The Late Quaternary history of the Kattegat Sea and the Swedish west coast. Sveriges Geologiska Undersökning. Serie C, 640, $1-487$.

Thomsen, M. S., 1990: Accelerator mass spectrometry. Applied to the radio isotopes $14 \mathrm{C}$ and $32 \mathrm{Si}$. $\mathrm{Ph}$. D. thesis, Institute of Physics, University of Aarhus, in press.

Walton, W. R., 1964: Recent foraminiferal ecology and paleoecology. In Imbrie, J. \& Newell, N. D. (eds.): Approaches to Paleoecology, 151-237. Wiley \& Sons, New York. 


\section{Appendix}

The sediments described by $H$.

Gry (1944)

$0.0-\quad 1.4 \mathrm{~m}$
$-\quad 3.0$
$-\quad 8.5$
$-\quad 9.9$

$-12.45$

$-14.3$

- 17.4

$-19.7$

$-20.1$

- 21.7

- 22.3

- 23.3

$-25.0$

$-26.55$

$-27.1$

$-\quad 28.55$

$-29.3$

$-\quad 31.0$

- 31.9

$-32.3$

$-\quad 33.9$
Postglacial, cross-

bedded marine sand

Marine gravel and

stones

Coarse to fine sand with stones

Sandy clay with coal

and a few grains of

mica

Fine, grey, clayey sand

with a little Jurassic

coal and shell-frag-

ments

Sandy clay

Rather fine, grey sand

Sandy clay with a few

coals

Dark grey, clayey fine

sand

Sandy clay with stones

Sand

Grey, sandy and stony clay

Alternating layers of sand and clay, $2-3 \mathrm{~cm}$

Grey, sandy clay with stones

Grey, clayey sand with coal

Grey, sandy clay

Medium grained, grey

sand

Sandy clay

Darker sticky clay

Medium grained, grey

sand

Sandy clay with shell-

fragments $-\quad 34.0$

- 56.5

$-72.7$

- 77.88

$-78.9$

$-79.7$

- 85.7

$-87.9$

$-98.0$

$-100.1$

$-122.0$

$-144.4$

$-146.9$

$-149.0$

$-151.0$

$-170.7$

$-188.1$

$-188.7$
Sand

Grey, stony clay with coal and shell-frag-

ments

Greenish, marine sticky clay

Alternating layers of sand and clay

Stony, grey, sandy clay with shells

Stony sand

Grey, sandy clay with stones

Rather coarse, grey

sand with great

amounts of bryozoans

(and stones)

Grey, sandy and stony

clay. Probably al-

ternating layers of sand and clay.

Stony sand

Grey, stony clay with alternating layers of sand and clay. Shells

Coarse, grey sand with stones and shells

Sandy clay

Coarse, grey sand with coal and shell-frag-

ments

Sandy clay

Grey, rather coarse to medium, stony and clayey sand with coal and shell-fragments

Rather sticky, stony clay with coal and shell-fragments

Sand 
$-188.8$

$-189.6$

- 192.25

$-206.7$

- 208.8

$-209.0$

$-215.75$

- 216.0

- 217.3
Clay

Sand

Grey, stony, sandy clay

Stony, medium to

rather coarse, gray

sand with shells

Stony clay

Sand

Stony clay

Sand

Dark grey, rather

sticky clay
$-218.6$

$-219.3$

$-219.9$

- 220.1

- 224.7

$-226.05$

- 227.0

- 228.81
Sand

Clay

Sand

Clay

Medium grained, grey, stony sand with shells

Dark grey, rather sticky, stony clay Medium, grey sand Clay 
Plates 1-2 


\section{PLATE 1}

Scale $=0.1 \mathrm{~mm}$

Foraminifera from Eemian Interglacial at Anholt

Fig. 1. Textularia sagittula Defrance 1824. Sample no. 112d.

Fig. 2. Quinqueloculina padana Perconig 1954. Sample no. 112a.

Fig. 3. Quinqueloculina padana Perconig 1954. Apertural view. Sample no. 112a.

Fig. 4. Bulimina marginata d'Orbigny 1826. Sample no. $112 \mathrm{~d}$.

Fig. 5. Globobulimina turgida (Bailey 1851). Sample no. 112d.

Fig. 6. Stainforthia fusiformis (Williamson 1858). Sample no. 112d.

Fig. 7. Uvigerina peregrina Cushman 1923. Sample no. 112d.

Fig. 8. Angulogerina angulosa (Williamson 1858). Sample no. 112d.

Fig. 9. Bolivina subspinescens Cushman 1922. Sample no. 112d.

Fig. 10. Bolivina subspinescens Cushman 1922. Edge view. Sample no. 112d.

Fig. 11. Cassidulina laevigata d'Orbigny 1826. Side view. Sample no. 112d.

Fig. 12. Cassidulina laevigata d'Orbigny 1826. Edge view. Sample no. 112d.

Fig. 13. Cassidulina reniforme Nørvang 1945. Sample no. 112d.

Fig. 14. Epistominella vitrea Parker 1953. Umbilical view. Sample no. 112d.

Fig. 15. Epistominella vitrea Parker 1953. Spiral view. Sample no. 112d. 
Plate 1
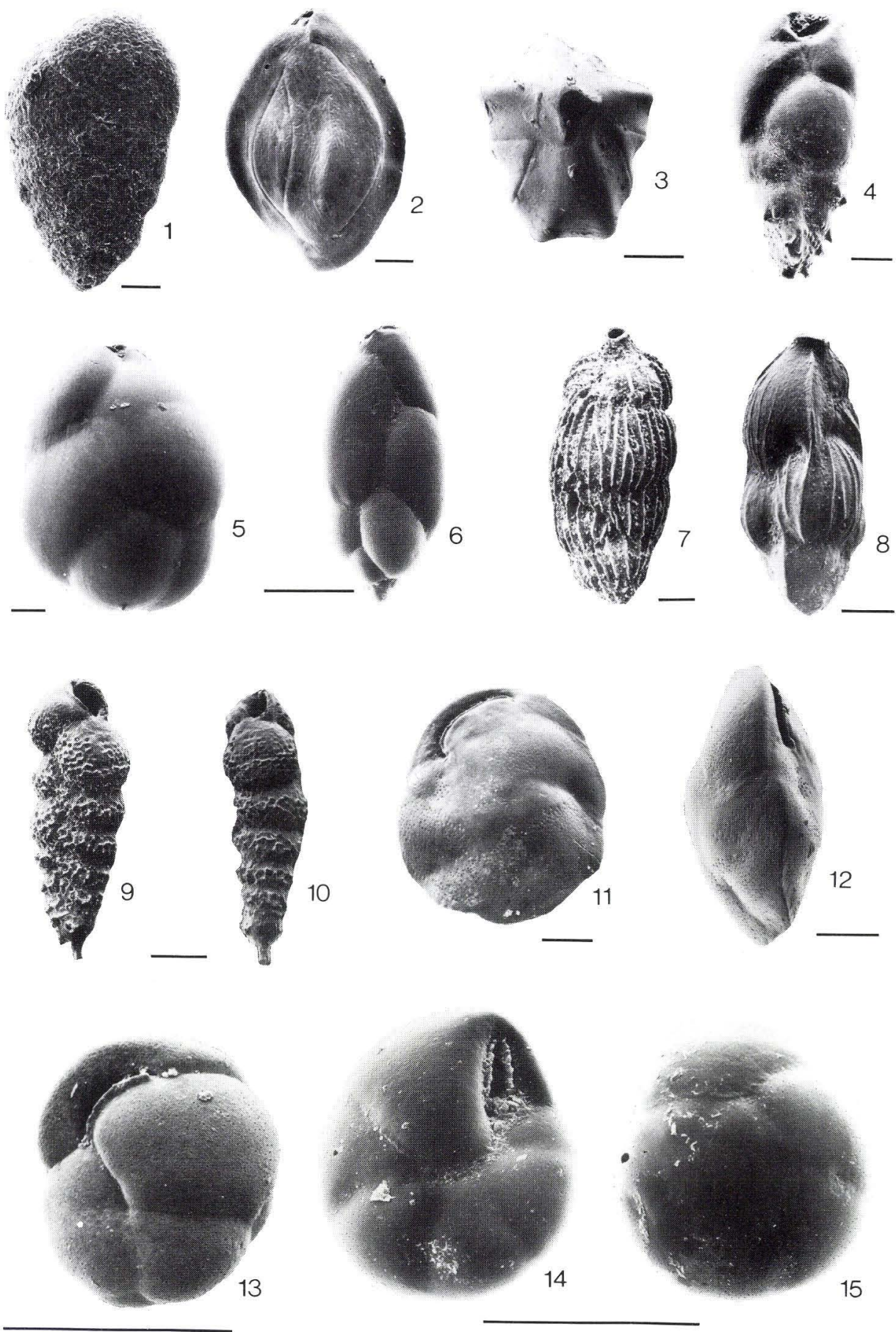


\section{PLATE 2}

Scale $=0.1 \mathrm{~mm}$

Foraminifera from Eemian Interglacial at Anholt

Fig. 1. Planulina ariminensis d'Orbigny 1826. Side view. Sample no. 112d.

Fig. 2. Planulina ariminensis d'Orbigny 1826. Edge view. Sample no. 112d.

Fig. 3. Hyalinea balthica (Schroeter 1783). Edge view. Sample no. 112d.

Fig. 4. Hyalinea balthica (Schroeter 1783). Side view. Sample no. 112d.

Fig. 5. Nonion barleeanum (Williamson 1858). Edge view. Sample no. 112d.

Fig. 6. Nonion barleeanum (Williamson 1858). Side view. Sample no. 112d.

Fig. 7. Nonionella iridea Heron-Allen \& Earland 1932. Side view. Sample no. 112d.

Fig. 8. Nonionella iridea Heron-Allen \& Earland 1932. Edge view. Sample no. 112d.

Fig. 9. Elphidium excavatum (Terquem 1876). Side view. Sample no. 112d.

Fig. 10. Elphidium excavatum (Terquem 1876). Edge view. Sample no. 112d.

Fig. 11. Ammonia batava (Hofker 1951). Umbilical view. Sample no. 112d.

Fig. 12. Ammonia batava (Hofker 1951). Edge view. Sample no. 112d.

Fig. 13. Ammonia batava (Hofker 1951). Spiral view. Sample no. 112d 
Plate 2
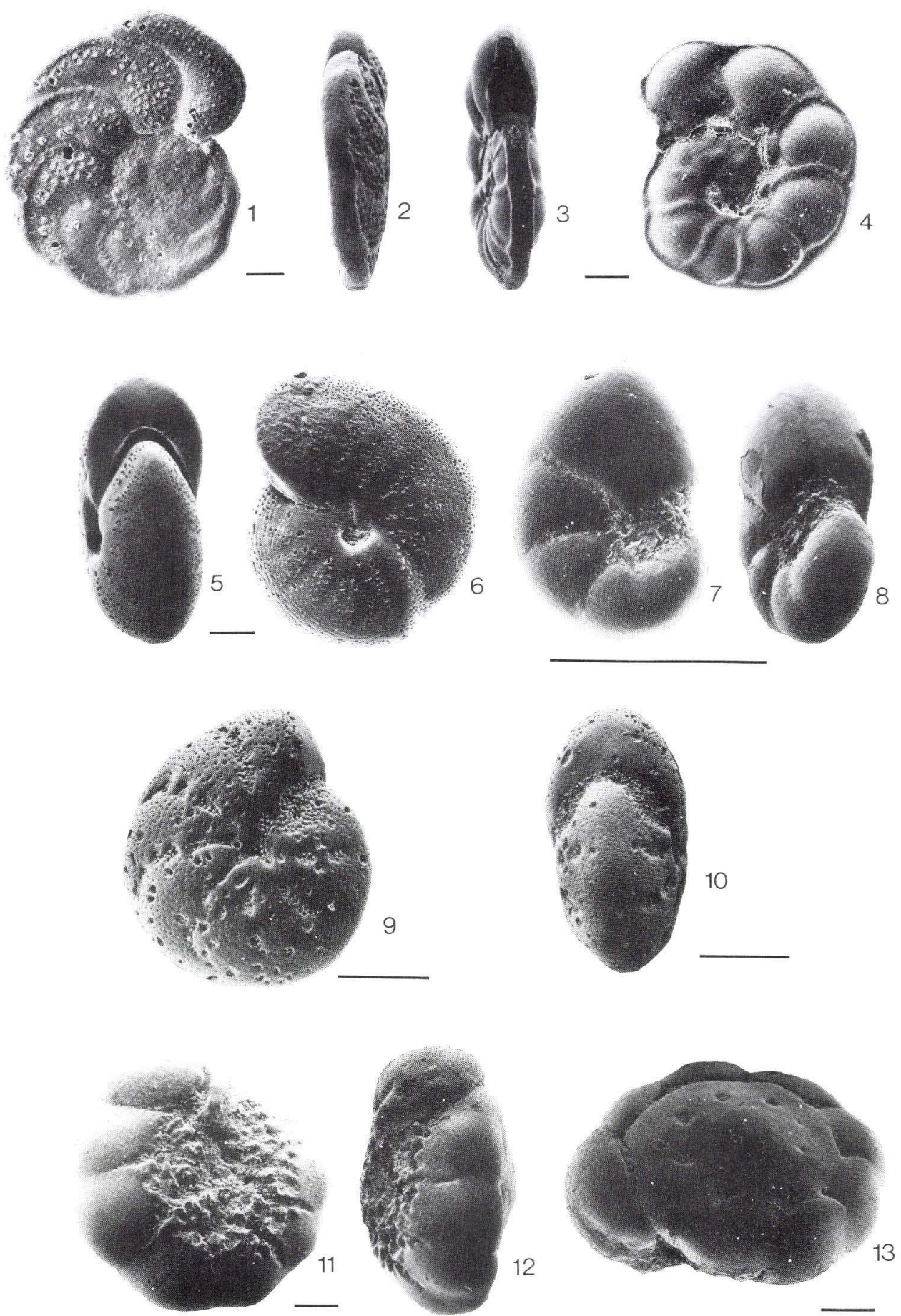
Fig. 9. Range chart for the Anholt boring no. 51.12. The percentage distributions of selected foraminiferal species are shown. Legend fig. 10. The bore site is $2.5 \mathrm{~m}$ above sea-level.

Foraminiferdiagram over boring $n r .51 .12, A n$ holt. Den procentuelle fordeling af udvalgte foraminiferarter er vist. Legende fig. 10. Borestedet er placeret $i$ kote $2,5 \mathrm{~m}$.

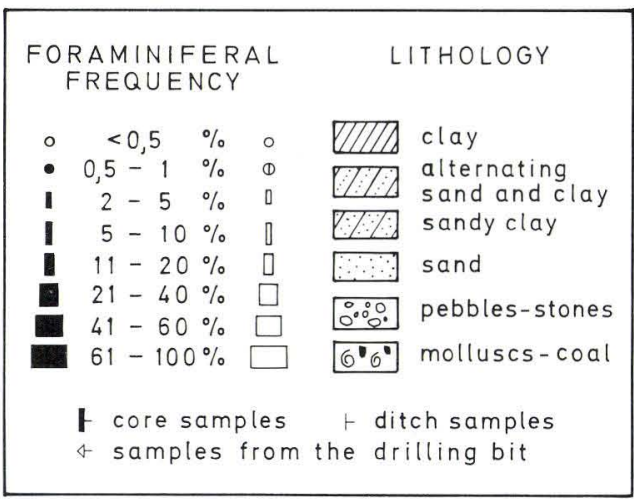

Fig. 10. Legend for fig. 9. The filled signatures and normal types are used for the core samples and the samples from the drilling bit. The open signatures and italics are used for the ditch samples.

Legende til fig. 9. De udfyldte signaturer og normal skrifttype er brugt til angivelse af kerne-og meiselprover. Åne signaturer og kursiv er benyttet til skylle- og sigteprøver. 


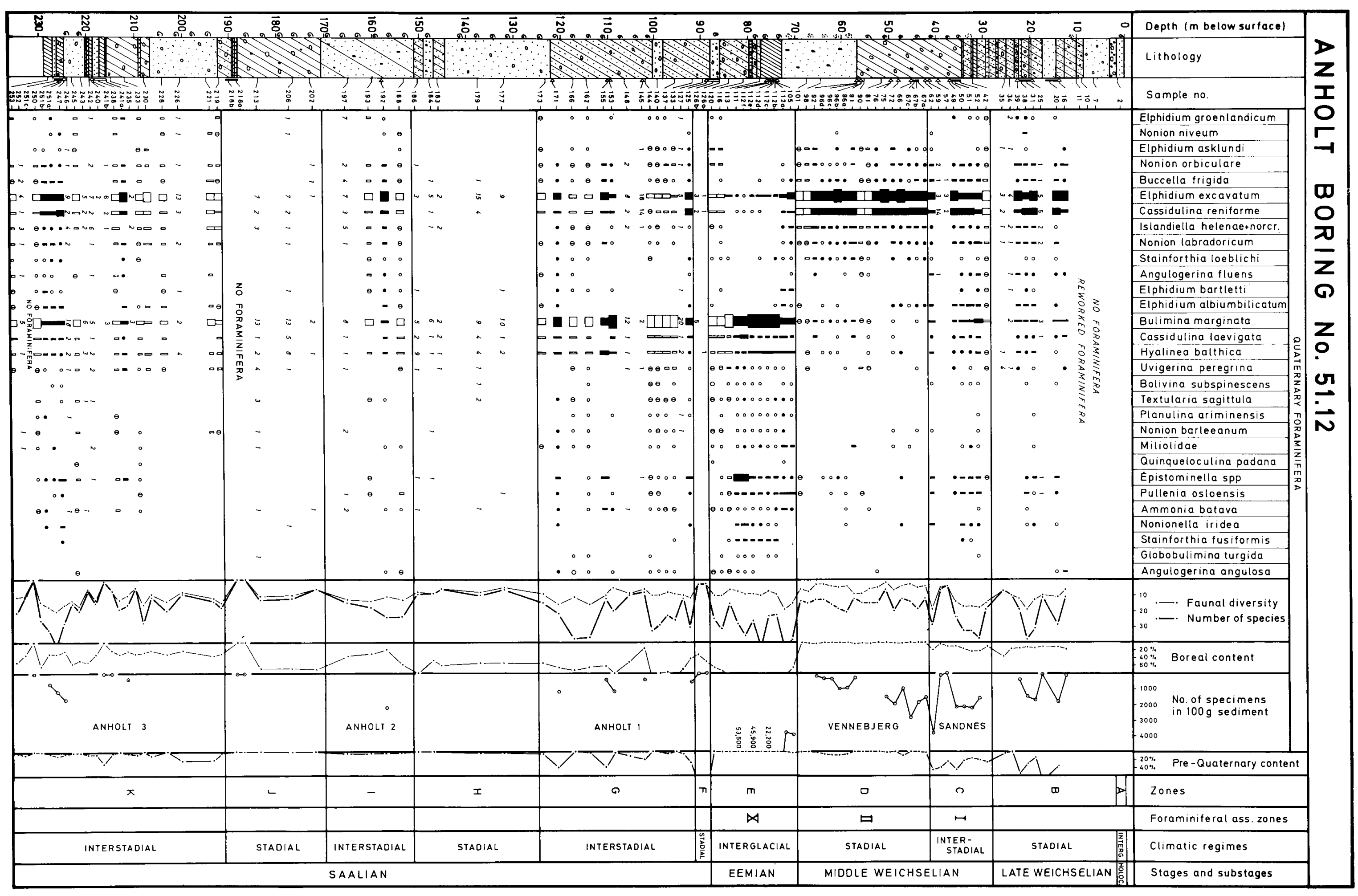


This paper describes and discuss the foraminiferal stratigraphy of a $229 \mathrm{~m}$ deep boring on the island of Anholt, situated between Denmark and Sweden, almost in the center of the Kattegat.

The author, furthermore, discuss the Quaternary stratigraphy of Anholt and resume the history of this almost $\mathbf{5 0}$ years old boring.

She, especially, demonstrates the exsistence of one Middle Weichselian Interstadial, Eemian Interglacial, and a thick pre-Eemian sequence of assumed Saalian age. 